\title{
A REVIEW ON LAWSONIA INERMIS: A POTENTIAL MEDICINAL PLANT
}

\author{
ALI ESMAIL AL-SNAFI \\ Department of Pharmacology, College of Medicine, Thi qar University, Iraq \\ Email: aboahmad61@yahoo.com
}

Received: 10 May 2019, Revised and Accepted: 15 Jul 2019

\begin{abstract}
Lawsonia inermis (Family: Lythraceae) contained carbohydrates, phenolic, flavonoids, saponins, proteins, alkaloids, terpenoids, quinones, coumarins, xanthones, fat, resin and tannins. It also contained 2-hydroxy-1,4-naphthoquinone (lawsone). Many alkaloids, naphthoquinone derivatives, phenolics and flavonoids were isolated from different parts of Lawsonia inermis. The pharmacological studies showed that Lawsonia inermis showed antibacterial, antifungal, antiparasitic, molluscicidal, antioxidant, hepatoprotective, central nervous, analgesic, anti-inflammatory, antipyretic, wound and burn healing, immunomodulatory, antiurolithiatic, antidiabetic, hypolipidemic, antiulcer, antidiarrhoeal, diuretic, anticancer and many other pharmacological effects. The current review will highlight the chemical constituents and pharmacological effects of Lawsonia inermis.
\end{abstract}

Keywords: Lawsonia inermis, Constituents, Pharmacology, Napthoquinone, Lawsone

(C) 2019 The Authors. Published by Innovare Academic Sciences Pvt Ltd. This is an open access article under the CC BY license (http://creativecommons.org/licenses/by/4.0/) DOI: http://dx.doi.org/10.22159/ijcpr.2019v11i5.35695

\section{INTRODUCTION}

Until the $19^{\text {th }}$ century, dyes produced from natural plants formed the basis of the cosmetic and food industries, Many plants in Iraq were used as natural dyes in addition to their traditional therapeutic uses, these included: Achillea santolina (Flowers: Yellow [1], Althaea officinalis and Althaea rosea (Tlowers: pink, Reddish pink, White) [2], Anchusa italica and Anchusa strigosa (Flowers: Pink-violet) [3], Anethum graveolens (Flower: Yellow) [4], Carthamus tinctorius (Sepal of flower: Red, Yellow, Green) [5], Chrozophora tinctoria (Aboveground: Purple) [6], Crocus sativus (Stigmata of flower: Orange, Yellow) [7], Cydonia oblonga (Leaf: Brown) [8], Euphorbia tinctoria (Aboveground: Blue, Yellow)[9], Glycyrrhiza glabra (Leaf: Yellow) [10], Gossypium herbaceum and Gossypium hirsutum (Leaf: Yellow) [11], Inula viscosa (Aboveground: Yellow)[12], Juglans regia (Bark, Root, Leaf, Bark of fruit: Brown) [13], Juniperus communis (Leaf: Green) [14] and Hibiscus sabdariffa (Petals: Yellow, Pink, Red) [15].

Lawsonia inermis Linn (Family: Lythraceae) which is commonly known as henna, mainly present in subtropical and tropical areas and is used in all over the world. It was used for over $9000 \mathrm{y}$ for its cosmetic values as a dye. The phytochemical analysis of Lawsonia inermis revealed the presence of carbohydrates, phenolic, flavanoids, saponins, proteins, alkaloids, terpenoids, quinones, coumarins, xanthones, fat, resin and tannins. It also contained 2-hydroxy-1,4naphthoquinone (lawsone). Many alkaloids, napthoquinone derivatives, phenolics and flavonoids were isolated from different parts of Lawsonia inermis. The pharmacological studies showed that Lawsonia inermis showed antibacterial, antifungal, antiparasitic, molluscicidal, antioxidant, hepatoprotective, central nervous, analgesic, anti-inflammatory, antipyretic, wound and burn healing, immunomodulatory, antiurolithiatic, antidiabetic, hypolipidemic, antiulcer, antidiarrhoeal, diuretic, anticancer and many other pharmacological effects. The current review will highlight the chemical constituents and pharmacological effects of Lawsonia inermis.

\section{Plant profile}

\section{Synonyms}

Alcanna spinosa, Casearia multiflora, Lawsonia alba, Lawsonia speciosa, Lawsonia spinosa, Lawsonia and Rotantha combretoides [16].

Taxonomic classification

Kingdom: Plantae, Subkingdom: Viridiplantae, Infrakingdom: Streptophyta, Superdivision: Embryophyta, Division: Tracheophyta,
Subdivision: Spermatophytina, Class: Magnoliopsida, Superorder: Rosanae, Order: Myrtales, Family: Lythraceae, Genus: Lawsonia, Species: Lawsonia inermis [17].

\section{Common names}

Arabic: henna; Bengali: mendi, mehedi; English: Egyptian-privet, henna, Jamaica-mignonette, mignonette-tree; French: henné; German: Hennastrauch; Hindi: mehndi; Indonesian: inai, pakar kuku; Portuguese: hésia, hena, alfeneiro; Spanish: alcana, alheña; Swedish: henna; Vietnamese: nhuôm móng taylâ mòn [18].

\section{Distribution}

Lawsonia inermis is generally considered as a native of Africa and Asia. It was distributed in Africa: Egypt, Ethiopia, Somalia, Sudan, Zaire,Niger, Benin, Burkina Faso, Cote D'Ivoire, Gambia, Ghana, Guinea, GuineaBissau, Liberia, Mali, Nigeria, Senegal, Sierra Leone, Togo, South Africa, Comoros, Seychelles; Asia: India, Pakistan, Sri Lanka. It is widely cultivated in tropical regions of the world, North and East Africa, the Arabian Peninsula, the Southern areas of the Middle East, and South Asia [19].

\section{Traditional uses}

Leaves of Lawsonia inermis provide an important cosmetic dye. Henna leaves were extensively used for centuries in the Middle East, the Far East and Northern Africa as dye for nails, hands, hair and textile. Henna was also used in treating skin problems, headache, jaundice, amebiasis and enlargement of the spleen $[20,21]$.

\section{Parts used medicinally}

Whole plant, roots, fruits, stem, leaves, barks, inflorescence, rhizome, bulbs, latex, seeds, flowers and oil were used in different ailments [20].

\section{Physiochemical characteristics}

Physiochemical investigation of leaf showed that the total ash was (14.60\%), acid insoluble ash (4.50\%), water soluble ash (3.0\%), loss on drying ( $4.5 \%)$, alcohol soluble extractive value $(3.8 \% \mathrm{w} / \mathrm{w})$ and aqueous extractive value $(5.0 \% \mathrm{w} / \mathrm{w})[22]$.

\section{Chemical constituents}

The preliminary phytochemical analysis of the aqueous extract of Lawsonia inermis revealed the presence of carbohydrates, phenolic compounds, flavonoids, saponins, proteins, alkaloids, terpenoids, 
quinones, coumarins, xanthones, $6 \%$ fat, $2-3 \%$ resin and $7-8 \%$ tannins [23-30].

Lawsonia inermis contained 2-hydroxy-1,4-naphthoquinone (lawsone). HPLC analysis showed that the extracts of Lawsonia inermis flowers, leaves and branches contained 116.9, 486.2 and $5.4 \mu \mathrm{g} / \mathrm{g}$ lawsone [31].

Polyphenols (equivalent to gallic acid), tannins (equivalent to catechin), flavonoids (equivalent to quercetin) and anthocyanins (equivalent to cyanindin) in the ethyl acetate extract were: $129.6 \pm 4.1,477.9 \pm 12.9,85.6 \pm 3.1$ and $0.75 \pm 0.02$; in petroleum ether extract were: $71.7 \pm 2.1,315.6 \pm 11.2,52.9 \pm 1.9$ and $1.98 \pm 0.06$; in ethanol extract were: $105.8 \pm 4.2,58.1 \pm 1.7,33.8 \pm 1.4$ and $5.48 \pm 0.17$ and in decoction were: $100.2 \pm 3.5,31.3 \pm 0.8,16.2 \pm 0.5$ and $1.86 \pm 0.05$ respectively [32].

Other napthoquinone derivatives: 1,3-dihydroxy naphthalene, 1,4napthaquinone, 1,2-dihydroxy-4-glucosylnaphthalene and 1,2,4trihydroxynaphthalene-2-0- $\beta$-D-glucopyranoside were also isolated from the leaves of Lawsonia inermis [28, 33, 34].

Many benzenoid derivatives, lawsoinermone, inermidioic acid, inermic acid, (E)-methyl 3-(4-hydroxyphenyl)acrylate, (E)-ethyl 3(4-hydroxyphenyl)acrylate, caffeoyl alcohol, ethyl 2-methyl benzoate, benzene-1,2-dicarboxylic acid, monomethyl orthophthalate, methyl 2-ethylbenzoate, methyl 2-methyl benzoate, and ethyl 2-methyl benzoate were isolated from the aerial part of Lawsonia inermis [34]. Two alkaloids, harmine and harmaline were also isolated from the ethanol extract of Lawsonia inermis leaves [35]. Five triterpenes were isolated from the methanol extract of Lawsonia inermis leaves included rosamutin, euscaphic acid, 1b,2b,3b,19a-tetrahydroxyurs-12-en-28-oic acid, ursolic acid and arjunic acid. The first four compounds were ursane-type triterpenes while the fifth compound was an oleane-type triterpene [36]. Nonterpenes derivatives were the main group of compounds in Lawsonia inermis essential oil, their percentage was $78 \%$ in Malaysian, $53 \%$ in Nigerian, $40 \%$ in Ethiopian and $19.8 \%$ in Tunisia samples [37-40]. Nine components were identified in the essential oil of leaves of Lawsonia inermis from Afar Region, Ethiopia included (\%): linalool 4.23, $\alpha$-terpineol 8.36, etherphenylvinyl 6.72, 1,3indandione 6.60 , eugenol 17.61, cis-hexahydro-8a-methyl $1,2 \mathrm{H}, 8 \mathrm{H}]-$ naphthalenedione 5.60, oxirane-tetradecyl 6.20, hexadecanoic acid 15.07 and phytol 10.17 [37]. The total phenols of ethyl acetate fraction of ethanolic extracts of Lawsonia inermis leaves were $30.80 \pm 1.90 \mathrm{GAE} / \mathrm{gm}$ and the total flavonoids were $79.16 \pm 2.72$ GAE/gm of dried extracts. The total phenols of petroleum ether fraction of ethanolic extracts of Lawsonia inermis leaves was $39.39 \pm 2.46 \mathrm{GAE} / \mathrm{gm}$ and the total flavonoids was $51.39 \pm 1.37 \mathrm{GAE} / \mathrm{gm}$ of dried extracts. While, the total phenols of chloroform fraction of ethanolic extracts of Lawsonia inermis leaves was $58.40 \pm 1.96 \mathrm{GAE} / \mathrm{gm}$ and the total flavonoids were $35 \pm 1.74 \mathrm{GAE} / \mathrm{gm}$ of dried extracts $[40,41]$. The total phenolics amount in the hexane, chloroform and methanolic extracts of henna seeds were $3.5 \pm 1.4,55.7 \pm 2.44$ and $457.5 \pm 3.4 \mathrm{~g}$ gallic acid equivalent/Kg of dry mass respectively. The total flavonoids amount in the hexane, chloroform and methanolic extracts of henna seeds were $21.6 \pm 2.4,120.7 \pm 3.9$ and $199.9 \pm 2.1 \mathrm{mg}$ quercetin equivalent $/ \mathrm{kg}$ dry mass respectively. While, the total tannins amount in the hexane, chloroform and methanolic extracts of henna seeds were $50.0 \pm 4.5$, $93.7 \pm 3.9$ and $28.0 \pm 3.5 \mathrm{mg}$ quercetin equivalent/kg dry mass respectively [42]. However, the calculated values for flavonoid and phenolic compounds were $94.19 \mathrm{mg} / \mathrm{gr}$ rutin equivalent and 126.38 $\mathrm{mg} / \mathrm{g}$ gallic acid equivalent, respectively in the $80 \%$ ethanol extract of the aerial organs of Lawsonia inermis [43]. Phenolic compounds isolated from Lawsonia inermis were included: lawsoniaside $(1,3,4-$ trihydroxynaphthalene 1,4-di- $\beta$-D-gluco-pyronoside), lalioside $(2,3,4,6$-tetrahydroxyacetoxy-2- $\beta$-D-glucopyranoside), lawsoniaside B (3-(4-O-a-D-glucopyranosyl-3,5-dimethoxy) phenyl-2E-propenol), syringinoside, daphneside, daphnorin, agrimonolide 6-0- $\beta$-Dglucopyranoside, (+)-syringaresinol 0 - $\beta$-D-glucopyranoside, (+)pinoresinol di-O- $\beta$-D-glucopyranoside, syringaresinol, di-O- $\beta$-Dglucopyranoside and isoscutellarin [44, 45].

Flavonoids isolated from Lawsonia inermis were: apigenin, apigenin-7glucoside, apigenin-4-glycoside, apigenin-4'-O- $\beta$-D-glucopyranoside, luteolin, luteolin-7-glucoside, luteolin-3-glucoside, kampferol, quercetin, isoscutellarin, tricin, kaempferin, isoquercitrin and (-)catechin, 7-hydroxy-3,5-dimethoxy-6,8-dimethyl flavone, 3, 7, 4', 5'Tetrahydroxy-6-methoxyflavone and 4'-hydroxyflavanone [46-49].

Tannin analysis of henna leaves powder showed that the tannin content, non tannin, total soluble, total solid was $11.12 \%, 22.64 \%$, $33.76 \%, 36.72 \%$ respectively.

Coumarins, lacoumarin (5-allyoxy-7-hydroxycoumarin), carbonates $A$ and B were isolated from whole Lawsonia inermis [50,51].

The compounds identified in the hexane fraction of crude methanol extract of Lawsonia inermis leaves were phenol, eicosane, nonadecane, celidoniol, hexadecanoic acid, ethyl-9,12 octadecadienoate, 9,12,15-octadecatrienoic acid and 1,2 benzene dicarboxylic acid. While, the compounds identified in the ethyl acetate fraction of crude methanol extract of Lawsonia inermis leaves were benzoic acid, methyl ester; 2,3 dihydrobenzo furan; 2-methoxy 4 vinyl phenol; pthalic anhydride; 1 - $\mathrm{H}$ indole-1,3 $(2 \mathrm{H})$-dione; $1(3 \mathrm{H})$ isobenzofuranone; 1,4 napthalenedione, 1,2,3-benzenetriol; phenol,2 methoxy-4 (2 propenyl); napthelene, 2 ethoxy; 2 (4H) benzofuranone; 1,2 benzene dicarboxylic acid; hexadecanoic acid; 9,12,15 octadecatrienoic acid; vitamin E and benzene, 1 isocyano 4 methyl. On the other hand 4H-pyran-4-one; 1,3-isobenzofurandione; 1(3H)-isobenzofuranone; n-hexadecanoic acid; 9,12-octadecadienoic acid ethyl ester; squalene and vitamin $\mathrm{E}$ were identified in the aqueous methanol fraction of Leaves of Lawsonia inermis [52].

In comparison of phytochemicals for Nigerian and Egyptian henna, it appeared that they contained $(\%)$ the following compounds respectively: dl-glyceraldehyde 4.83 and $4.14,2$-propanone, 1, 3dihydroxy 3.43 and 3.04, 4H-pyran-4-one, 2, 3-dihydro-3, 5dihydroxy-6-methyl-and 1.97, glycerane 1.92 and-, coumarane 2.90 and $6.89,1,2$-benzenedicarboxilic acid 2.18 and-, 1, 3-indandione 4.16 and-, benzomide 2.09 and-, alpha-Guai-and 2.30, tetradecane 1.25 and-, 2-Acetyl benzoic acid 4.29 and 2.72, 3-methyl-5-propyl 3.87 and-, benzene dicarboxilicaciddiethyl ester2-(2-Isopropenyl cyclopentyl methoxy) 7.04 and-, tetrahydropyran-and 5.18, alpha-Dglucopyranoside, metyl, alpha-D-7.75 and-, benzene, (1methyldecyl)-and 5.47, benzene(1-propylnonyl)-and 3.82, benzene, (1-ethyldodecyl)-and 7.67, octanal, 2-(phenylmethylene) 3.03 and-, benzene, (1-methyllundecyl)-and 4.47, 1, 4-naphtoquinone, 3hydroxy 9.87 and 7.40, benzene, (1-ethyldecyl)-and 2.94, 1, 4naphtoquinone, 2-amino 19.35 and 4.64, hexanoic acid-and 8.57, 9, 12, 15-octadecatnen-1-ol-and 11.69 and di-n-octyl phthalate 22.03 and 17.09 [53]. However, analysis of Lawsonia inermis essential oil from Tunisia showed that apocarotenoids were the main group of constituents $33.6 \%$, followed by the non-terpene derivatives $19.8 \%$, oxygenated sesquiterpenes $12.4 \%$ and monoterpene hydrocarbons $9.8 \%$, in addition to sesquiterpene hydrocarbones $8.2 \%$, oxygenated monoterpenes 5.6\%, oxygenated diterpenes $3.0 \%$ and diterpenehydrocarbons $1.6 \%$. However the compounds identified in the essential oil and their percentage were: $(E)$-2-hexanal 0.2 , tricyclene 3.0 , sabinene $1.0, \beta$-pinene $0.1,6$-mehty-5-hepten-2-one 0.1 , myrcene $0.5, \alpha$-terpinene $0.4, p$-cymene 0.4 , limonene $1.0,(E)-\beta$ ocimene $0.2, \gamma$-terpinene $1.0, p$-cymenene 0.3 , terpinolene 0.6 , linalool 1.2, N-nonanal 0.6, 1,3,8-p-menthatriene 0.1 , cis- $p$-mentha2,8-dien-1-ol 0.3 , camphor 0.2 , trans-verbeno 0.2 , neroloxide 0.1 , (E)-2-nonen-1-al 0.2 , terpinen-4-ol 0.3 , safranal 0.3 , N-decanal 0.3 , trans-pulegol 1.0, trans-carveol 0.3 , cis-pulegol 0.1 , ascaridole 0.2 , isobornylacetate 0.6 , carvacrol 0.7 , nerylacetate $1.6, \alpha$-copaene 0.1 , longifolene 0.1 , dodecanal $0.2, \beta$-cariophyllene 0.9 , cis-dictamol 0.2 , $\alpha$-guaiene 0.3 , geranylacetone $13.4, \gamma$-muurolene 0.2 , germacrene $0.6,(E)$ - $\beta$-ionene 2.9 , cis- $\beta$-guaiene $0.5, \alpha$-muurolene $1.5,(E-E)-\alpha$ farnesene 0.9 , trans- $\gamma$-cadinene $1.2, \delta$-cadinene $1.5, \beta$-thujaplicinol 3.3 , $\alpha$-cadinene $0.3,(E)$-nerolidol 1.4 , globulol 0.3 , thujapsan-2- $\alpha$-ol 1.1, cartol 0.4 , guaiol 0.7, 5-epi-7- $\alpha$-eudesmol 2.2, $\alpha$-acorenol $0.7, \beta$ acorenol 0.3 , epi- $\alpha$-cadinol 1.2, $\alpha$-muurolol 0.2 , $\alpha$-cadinol 0.7 , intermediol $0.2, \mathrm{~N}$-tetradecanol $0.5, \beta$-bisabolol 0.2 , elemolacetate 0.5 , $\alpha$-bisabolol 0.2, hetadecane 0.4, $(Z-E)$-farnesol 0.1, $(E-E)$-farnesol 0.5 , tetranoicacid $3.1,(Z-E)$-farnesylacetate 0.2 , khusinolacetate 0.4 , cyclopentadecanolide $0.2,(E-E)$-farnesylacetate 1.5 , Hexahydrofarnesylacetone 11.5 , farnesylacetone 5.5 , methylhexadecanoate 1.3 , phytol 2.0, hexadecanoic acid 8.3, manoyloxide 1.0 , abietatriene 0.5 and abietadiene $1.0 \%$ [40]. A total of 72 components were identified 
in volatile oil of six henna samples. The samples were differ in their contents, the main identified chemical groups were aliphatic compounds (9.0-64.7\%), terpenoids (5.8-45.5\%) and aromatics (7.9-45.2\%), with alkanes $(0.9-18.5 \%)$, aldehydes $(2.1-18.8 \%)$ and carboxylic acids (3.1-29.3\%), monoterpenes $(3.4-30.0 \%)$ and sesquiterpenes (0.8-23.7\%), and phenyl propanoids (0.6-43.1\%). The major constituents of these groups were n-hexadecane $0.5-$ $4.7 \%)$, (2E)-hexenal (0.5-11.7\%), acetic acid (2.8-24.5\%), limonene (0.8-14.7\%), carvol (3.8-7.1\%), geranyl acetone (1.4-7.9\%) and (E)caryophyllene (3.3-8.4\%), and (E)-anethole (0.6-35.0\%) [54].

Mineral analysis of 25 populations of Lawsonia inermis, collected from the coastal oases of Gabès in the South-East of Tunisia, showed that sodium content in leaves varied from 0.08 to $0.69 \%$, while in stems, 0.08 to $0.46 \%$. The potassium content varied from 0.16 to $0.47 \%$ in the leaves and 0.15 to $0.81 \%$ in the stems. The calcium content was 0.2 to $0.41 \%$ in the leaves and 0.11 to $0.47 \%$ in the stems. The magnesium content 0.09 to $0.23 \%$ in the leaves and 0.03 to $0.11 \%$ in the stems. The phosphorus content 2.57 to $6.29 \%$ in the leaves and 2.73 to $9.84 \%$ in the stems. The copper content 0.06 to $1.87 \%$ in the leaves and from traces to $11.27 \%$ in the stems. The zinc content in the leaves varied from 0.47 to $2.92 \%$ and in the stems from 0.2 to $7.39 \%$. The iron content 4.03 to $28.77 \%$ in the leaves and 1.17 to $15.85 \%$ in the stems. The manganese content 0.27 to $1.28 \%$ in the leaves and 0.14 to $0.95 \%$ in the stems. The nitrogen matter content was varied from 0.14 to $4.72 \%$ in the leaves and from 0.17 to $0.56 \%$ in the stems [20].

\section{Pharmacological effects}

\section{Antimicrobial effects}

Different extracts of Lawsonia inermis leaves (ethanol, ethyl acetate and $n$-hexane) were evaluated for their antibacterial potential (1000 $\mu \mathrm{g} / \mathrm{ml}$ ) against Gram negative and Gram-positive bacterial strains (Proteus mirabilis, Pseudomonas aeruginosa, Staphylococcus epidermidis and Enterococcus faecalis) using disc diffusion assay method. All extracts possessed antibacterial activity against all the tested bacteria. Ethanol extract showed the highest antibacterial effects followed by ethyl acetate and $n$-hexane extracts [55].

Antibacterial activity of Lawsonia inermis was determined against six bacterial strains [Escherichia coli (MTCC No. 40), Staphylococcus aureus, Bacillus subtelis (MTCC No. 10619), Salmonella typhi (MTCC No. 3231), Klebsiella and Pseudomonas aeruginosa (MTCC No. 424)] by disc diffusion method. Crude ethanolic, hexane, ethyl acetate and aqueous methanol fraction possessed antibacterial activity against all the tested bacterial strains especially when used as $20 \mathrm{mg} / \mathrm{disk}$ [52]. The ethanol extract of Lawsonia inermis leaves exerted antibacterial effect against Bacillus subtilis, Salmonella typhi, Sal. paratyphi, Pseudomonas aeruginosa, and Staphylococcus aureus, the MIC values of the ethanol extract were 800, 1200, 1600, 4000, and $1200 \mu \mathrm{g} / \mathrm{ml}$, respectively[56]. Antibacterial activity of Lawsonia inermis extracts was studied against Salmonella typhi (MTCC-733). Methanol extract showed highest inhibition zone $(13.74 \pm 1.52 \mathrm{~mm})$ at $20 \mathrm{mg} /$ disc, followed by ethyl acetate fraction $(12.5 \pm 1.32 \mathrm{~mm})$ and hexane fraction $(11.66 \pm 1.5 \mathrm{~mm})$ at the same concentration. Quinone content of the extracts was responsible for antityphoid activity of Lawsonia inermis extracts [30]. The antibacterial activity of aqueous and alcoholic extracts of leaves of Lawsonia inermis was studied against Staphylococcus aureus and Staphylococcus epidermidis isolated from clinical cases of acne vulgaris. Alcoholic extracts showed more potent antibacterial effect than aqueous extracts against the tested bacteria, Staphylococcus epidermidis was more susceptible than Staphylococcus aureus. The biggest diameter of inhibition zone (22 $\mathrm{mm}$ ) was recorded for $1000 \mu \mathrm{g} / \mathrm{ml}$ of aqueous extract against Staphylococcus epidermidis. The range of minimal inhibitory concentration (MIC) for all concentrations was 200-700 $\mu \mathrm{g} / \mathrm{ml}$ [57]. The antibacterial effects of ethanol, petroleum ether and chloroform extracts of Lawsonia inermis leaves were investigated against Gram-positive: Staphylococcus aureus, Bacillus cereus, Staphylococcus haemolytica, Bacillus subtilis, Bacillus megaterium, Sarcina lutea and Gram-negative: Escherichia coli, Klebsiella sp., Klebsiella pneumonia, Pseudomonas aeruginosa, Salmonella typhi, Shigella dysenteriae, Shigella shinga, Shigella sonnei and Pseudomonas sp. The zone of inhibition of ethanol extract of
Lawsonia inermis, ranged from $7.20 \mathrm{~mm}$ (against Escherichia coli) to $17.25 \mathrm{~mm}$ (against Shigella dysenteriae). The lowest $(156.25 \mu \mathrm{g} / \mathrm{ml})$ and highest $(2500 \mu \mathrm{g} / \mathrm{ml})$ MIC was observed against Shigella dysenteriae and Escherichia coli, respectively. The highest and lowest zone of inhibition of petroleum ether extract was $15.03 \mathrm{~mm}$ and 7.40 $\mathrm{mm}$ against Shigella dysenteriae and Sarcina lutea respectively. Chloroform extract showed antibacterial activity against Staphylococcus aureus, Bacillus megaterium, Shigella shinga, Klebsiella pneumonia and Pseudomonas aeruginosa. The highest effect was recorded against Klebsiella pneumonia $(12.23 \mathrm{~mm})$ and the lowest against Staphylococcus aureus $(8.30 \mathrm{~mm})$ [58]. The antimicrobial effect of water and chloroform extracts of the leaves of Lawsonia inermis $(10-80 \mathrm{mg} / \mathrm{ml})$ was investigated against the primary invaders of burn wounds (Staphylococcus aureus, Streptococcus sp, Pseudemonas aeruginosa, Candida albicans, Fusarium oxysporum, and Aspergillus niger) using in vitro agar incorporation method and well diffusion methods. Both leaves extracts inhibited the growth of A. niger, F. oxysporum, Streptococcus sp and $S$. aureus [59]. The ethyl acetate and butanolic fractions of Lawsonia inermis were prepared from a hydro-methanolic extract $(70 \%)$ and their antibacterial effect was investigated against $P$. aeruginosa ATCC 27853 and six clinical isolates of $P$. aeruginosa obtained from different skin infections in diabetic patients. The results showed that the extracts possessed antibacterial properties against all the tested isolates. However the butanoic fractions showed the highest effect with MIC of $3.12-6.25 \mathrm{mg} / \mathrm{ml}$ the biofilm formation was decreased when incubated with the MIC of butanolic fraction, while, MIC of ethyl acetate extracts did not affect biofilm formation in all isolates of $P$. aeruginosa [60]. The antimicrobial activity of methanol, ethanol and aqueous dried Lawsonia inermis extract was studied against some human bacterial ( $S$. aureus, $S$. mutans, $P$. aeruginosa) and fungal isolates (A. niger, A. flavus and Fusarium). Using disc diffusion and well diffusion method. The maximum antibacterial activity was possessed by methanol and ethanolic extracts against the tested bacteria and fungi [61]. The antimicrobial activities of Lawsonia inermis leaf extract and 2hydroxy-1,4-naphthoquinone analogues were studied against many food-borne bacteria (Bacillus cereus, Listeria monocytogenes, Salmonella enterica, Shigella sonnei, Staphylococcus epidermidis, and S. intermedius). 2-Hydroxy-1,4-naphthoquinone showed strong activities against the tested bacteria, but it possessed no antibacterial activities against $S$. typhimurium. Hydroxyl (2-hydroxy1,4-naphthoquinone and 5-hydroxy-1,4-naphthoquinone), methoxy (2-methoxy-1,4-naphthoquinone), and methyl (2-methyl-1,4naphthoquinone, and 5-hydroxy-2-methyl-1,4-naphthoquinone) possessed potent activities, whereas bromo (2-bromo-1,4naphthoquinone and 2,3-dibromo-1,4-naphthoquione) and chloro (2,3-dichloro-1,4-naphthoquinone) exhibited no activity against the tested bacteria [62]. The chloroform, ethanol and water extracts $(100,200,400$ and $800 \mu \mathrm{g} / \mathrm{ml})$ of the leaves of Lawsonia inermis were investigated for antibacterial activity against Staphylococcus aureus, Bacillus subtilis, Escherichia coli and Proteus vulgaris by cupplate agar diffusion method. Based on MIC, chloroform and water extracts showed antibacterial activity against all the tested bacteria, while ethanol extract possessed no activity against Staphylococcus aureus and Bacillus subtilis [63]. The antibacterial effects of water, alcoholic and oily extracts of Lawsonia inermis leaves was investigated against Staphylococcus aureus Staphylococcus epidermidis (Co-agulase negative Staphylococci, CONS), ß-hemolytic Streptococci and Pseudomonas aeruginosa. Alcoholic and oily extracts were more effective than the water extract. Alcoholic extracts showed the highest antibacterial activity with MIC of 0.125 $0.150 \mu \mathrm{g} / \mathrm{ml}$ against $ß$-hemolytic Streptococci and against CONS was $0.125-175 \mu \mathrm{g} / \mathrm{ml}$. Oily extracts had MIC of $0.25-0.30 \mu \mathrm{g} / \mathrm{ml}$ against Staphylococcus epidermidis (CONS). Both alcoholic and oily extracts had the same MIC $(0.5 \mu \mathrm{g} / \mathrm{ml})$ on Staphylococcus aureus. Alcoholic extracts were also more effective on Pseudomonas aeruginosa with MIC of $0.5-0.57 \mu \mathrm{g} / \mathrm{ml}$ than oily extract (MIC of $0.20-0.28 \mu \mathrm{g} / \mathrm{ml}$ ) [64]. In comparison with distil water, ethanol, methanol, ethyl acetate and acetone extracts of Lawsonia inermis leaves showed larger diameter inhibition zone: 18, 19.83, 17.16, 16.33, $16.5 \mathrm{~mm}$ respectively, against Pseudomonas eroginosa, Pseudomonas oryzihabita, Proteus varaplis, Klepsila pneumonia and Staphylococcus aureus. The results also revealed that MIC of acetone extract of 
Lawsonia inermis leaves was $6 \mathrm{mg} / \mathrm{ml}$ for Pseudomonas eroginosa and $7 \mathrm{mg} / \mathrm{ml}$ for Pseudomonas oryzihabita and $11 \mathrm{mg} / \mathrm{ml}$ for Proteus varaplis, Klebsila pneumonia and Staphylococcus aureus [65]. Crude extracts of fresh and dry Lawsonia inermis leaves and seeds were investigated for antimicrobial activity against 3 standard bacterial strains (Staphylococcus aureus, Escherichia coli and Pseudomonas aeruginosa), in addition to Candida albicans. The fresh and dry leaves and seeds possessed antimicrobial effect against the bacterial strains and $C$. albicans. Dry leaves extract showed the highest effects against all the tested bacteria strains as well as against $C$. albicans. Leaves (fresh and dry) possessed antimicrobial activity higher than seeds (fresh and dry) [66]. The antimicrobial activity of the aqueous extract from leaves of Lawsonia inermis (130, 260, 390, 520, 650, 780 and 910 ppm) was studied against two Gram-positive and five Gram-negative bacteria (Staphylococcus aureus, Bacillus subtilus, Klebsiella pneumonia, E. coli, Pseudomonas aeruginosa, Proteus vulgarius, Yersinia enterocolitica) and three fungal isolates (Aspergillus niger, Aspergillus flavus, and Penicillum notatum). Grampositive bacteria were completely inhibited by henna at concentrations of $650 \mathrm{ppm}$ and Gram-negative bacteria were inhibited by henna concentration between 780 to 910 ppm. Growths of all fungal isolates were inhibited by henna extract at a concentration of $1300 \mathrm{ppm}$ [67]. The antibacterial activity of an aqueous extract of henna leaf was studied against 3 Gram-positive and 5 Gram-negative bacteria. Extract inhibited the growth of both Gram-positive and Gram-negative bacteria. The diameters of inhibition: Bacillus cereus: $20 \mathrm{~mm}$, B. anthracis: $40 \mathrm{~mm}$, Escherichia coli: $20 \mathrm{~mm}$, Proteus vulgaris: $25 \mathrm{~mm}$, Staphylococcus aureus: $15 \mathrm{~mm}$, Erwinia carotovora: $20 \mathrm{~mm}$, Agrobacterium tumefaciens: $30 \mathrm{~mm}$ and Xanthomonas campestris: $32 \mathrm{~mm}$ [68]. The antimicrobial activity of Lawsonia inermis leaves suspensions were studied against urinary clinical isolates (E. coli, P. mirabilis, K. pneumoniae, P. aeroginosa and Staphylococcus aureus). Lawsonia inermis leaves suspensions possessed definite antimicrobial activity [69]. The antibacterial effects of Lawsonia inermis leaves were studied against Staphylococcus aureus, Escherichia coli, Klebsiella pneumonia, Proteus, and Pseudomonas aeruginosa. Only the ethyl alcoholic extract showed antibacterial effects at concentration of $500 \mu \mathrm{g} / \mathrm{ml}$ onwards. Whereas, hexane and chloroform extracts did not possess antibacterial effects even at concentration of $(1000 \mu \mathrm{g} / \mathrm{ml})$ [70]. The antimicrobial effect of water, methanol and chloroform crude extracts of Lawsonia inermis leaf was studied against 6 human pathogenic fungi (Epidermophyton floccosum, Mirosporum audouinii, Trichophyton rubrum, Trichophyton concentricum, Trichophyton tonsurans and Candida albicans) and 4 bacteria (Staphylococcus aureus, Bacillus subtilis, Escherichia coli and Pseudomonus aeruginosa). The water extract was more potent followed by methanol, while chloroform extract showed the least antimicrobial effect. The growth of all pathogens was inhibited to varying degrees by increasing the concentration of the extract [71]. The antibacterial activity of the crude ethanolic extract of Lawsonia inermis was studied against a wide array of different microorganisms including a laboratory standard bacterial strain of Pseudomonas aeruginosa (NCTC 10662) and eleven fresh clinical isolates of P. aeruginosa. The ethanolic extract of Lawsonia inermis possessed antibacterial activity against all isolates [72]. The antibacterial activity of extracts of leaves of Lawsonia inermis (100, 200 and 300 $\mathrm{mg} / \mathrm{ml}$ ) was studied against Bacillus subtilis and E. coli. The extracts (hexane, ethyl acetate, chloroform, acetone and acetonitrile) were effective against all strains. Ethyl acetate extract was more potent than tetracycline $(25 \mu \mathrm{l} / \mathrm{ml})$ while; chloroform produced inhibitory zone similar to that of tetracycline [73]. This antimicrobial effectiveness of Lawsonia inermis plant extract (alcoholic, aqueous and silver nanoparticles) was studied against the growth of different Gram-positive and Gram-negative bacteria at concentration of 80 $\mathrm{mg} / \mathrm{l}$. Alcoholic, hot and cold water extracts showed the highest antimicrobial effect on the growth of $S$. aureus (inhibition zone 26 $\mathrm{mm}$ ) followed by the $P$. aueroginosa $(22 \mathrm{~mm})$ and $C$. albicans $(17$ $\mathrm{mm}$ ), while silver nano-particles of the plant gave the highest inhibition area $(30 \mathrm{~mm})$ on the growth of the $S$. aurous, followed by the $P$. aueroginosa (26 mm), Strep. pyogein $(25 \mathrm{~mm})$, and $C$. albicans $(18 \mathrm{~mm})$ [74]. The antibacterial effects of aqueous and alcoholic extracts of Lawsonia inermis leaves against Streptococcus pyogenes were investigated in vitro by using agar well diffusion method and in vivo using laboratory mice by treating it with prepared ointment from these extracts compared with gentamicin. Alcoholic extracts possessed the highest antibacterial activity (inhibition zone 18.2$28.2 \mathrm{~mm}$ ) in comparison with $26.2 \mathrm{~mm}$ for gentamicin. The recovery period was $11 \mathrm{~d}$ for an ointment prepared from alcoholic extract in a concentration of $5 \%$, in compared with $10 \mathrm{~d}$ for gentamicin in experimentally infected skin of mice by $S$. pyogenes using scratching. Histologically, in Lawsonia inermis treated group there were increased well-organized bands of collagen, more fibroblasts and few inflammatory cells compared with the control [75]. The antibacterial activity of dichloromethane (DCM), ethyl acetate and ethanol of fruits, flowers and leaves of Lawsonia inermis was studied against some pathogenic bacteria. All the test extracts (except DCM extract of flower) revealed inhibitory effect against all the tested bacteria. The highest inhibitory effect was possessed by ethyl acetate extract of flower against Staphylococcus aureus and Pseudomonas aeruginosa, and ethyl acetate extract of fruit against Escherichia coli and Bacillus subtilis. The ethyl acetate and ethanol extracts of flower, fruit and leaf exerted inhibitory activity at 1 $\mathrm{mg} / 100 \mu \mathrm{l}$ against all the test bacteria [76]. The antimicrobial of the of aqueous and methanolic extracts $(25 \mu \mathrm{l}$ from the extracts, 250 $\mathrm{mg} / \mathrm{ml}$ crude extract) of Lawsonia inermis was studied against Bacillus species, Staphylococcus aureus, Klebsiella pneumonia, Proteus species, Escherichia coli, Pseudomonas aeruginosa, Candida albicans and Microsporum species. The aqueous extract possessed antimicrobial effects against Bacillus species, Staphylococcus aureus, Proteus species and Candida albicans with MIC of 8, 11, 14, $15 \mathrm{~mm}$ respectively, while methanolic extracts was active against Bacillus species, Staphylococcus aureus, Klebsiella pneumonia, Proteus species and Candida albicans with MIC of $15,19,11,20,14 \mathrm{~mm}$ respectively [77]. The antifungal effect of ethanolic extract of crude lawsone was tested in comparison with listerine mouth wash in diabetics wearing dentures. Each subject was given distilled water at baseline and Colony Forming Units (CFU) of candidal species was determined. Post therapeutic samples were then collected $1 \mathrm{hr}$ and 1 week following drug usage and they were further advised to use given mouthwashes twice daily with volume of $5 \mathrm{ml} /$ rinse for 30 seconds and CFU was evaluated. Crude lawsone mouthwash showed superior antifungal activity when compared to listerine mouthwash. Lawsone was appeared more effective in reducing CFU, at $1 \mathrm{hr}$ and $1 \mathrm{w}$ of using the mouth wash $(\mathrm{p}<0.01)$. Subjective symptoms like taste and smell were determined by Chi-square test, good taste was felt for lawsone and olfactory satisfaction was good with Listerine $(\mathrm{p}<0.01)$. Burning sensation was found to be more with listerine mouth wash [78]. The Lawsonia bark extracts possessed fungistatic against Microsporum gypseum and Trichophyton mentagrophytes at concentration of 1:30 (W/V), however, it became fungicidal at 1:10 (W/V) concentration. Furthermore, the extract showed broad fungi toxic spectrum when tested against 13 ringworm fungi. Fungitoxicity of the extract remained unaltered at high temperature, on autoclaving and after storage [79]. Anti-Candida activities of ethanol extracts of Lawsonia inermis leaf was studied versus nystatin and fluconazole. The MIC90 for Lawsonia inermis against Candida albicans was $0.1 \mu \mathrm{g} / \mathrm{ml}$ and against Candida glabrata was 0.05 $\mu \mathrm{g} / \mathrm{ml}$, while, the MIC90 value for nystatin for both species was $0.035 \mu \mathrm{g} / \mathrm{ml}$, and MIC90 value for fluconazole for C. albicans was 0.5 $\mu \mathrm{g} / \mathrm{ml}$ and for C. glabrata was $2 \mu \mathrm{g} / \mathrm{ml}$ [80]. Lawsonia inermis ethyl acetate extract completely inhibited the growth of $C$. albicans. It also exhibited dose-dependent inhibitory activity against two major virulent enzymes of C. albicans, proteases (27-33\%) and phospholipases (44.5\%). It also completely inhibited both the isoforms of constitutive candidal enzyme aspartate dehydrogenase and affecting amino acid biosynthesis [81]. The antifungal effect of Lawsonia inermis (vaginal creams of $2 \%$ or $4 \%$ of Lawsonia inermis) was studied in rats infected vaginally with C.albicans. Before the treatment, the mean colony forming units (CFU) was $213.6 \pm 10.08$ and $334.42 \pm 20.32$ in the $2 \%$ and $4 \%$ henna groups, respectively, one week after treatment, the mean CFUs were zero for all groups except for the $2 \%$ henna and zero in all groups, two weeks after the treatment $(\mathrm{p}<0.001)$ [82]. The antifungal activity of Lawsonia inermis was investigated against clinical dermatophytes species (70 clinical isolates) representing six different species; Trichophyton rubrum, Trichophyton mentagrophytes, Microsporum canis, Trichophyton tonsurans, Epidermophyton floccosum and 
Trichophyton violaceum. The agar diffusion method showed high antifungal activity against all dermatophytes species (20 to $50 \mathrm{~mm}$ inhibition zone) [83]. In vitro antifungal effect of the chloroform, methanol and aqueous extracts of Lawsonia inermis were evaluated against four dermatophytic species (Trichophyton mentagrophytes, Trichophyton rubrum, Microsporum gypseum and Microsporum fulvum). MIC of $100 \mathrm{mg} / \mathrm{ml}$ of chloroform, methanol and aqueous extracts were $10-14,13-17$ and $19-26 \mathrm{~mm}$, respectively [84]. The antifungal effect of lawsone and (ethanol, chloroform, ethyl acetate and diethyl ether extracts) of Lawsonia inermis were investigated against filamentous fungi. The results revealed that lawsone showed potent antifungal effect, its MIC against Fusarium oxysporum was 12 $\mu \mathrm{g} / \mathrm{ml}$ and against Aspergillus flavus was $50 \mu \mathrm{g} / \mathrm{ml}$. Among extracts, only the ethanol extract showed interesting MIC $(230 \mu \mathrm{g} / \mathrm{ml}$ of crude extract) against $F$. oxysporum compared with other extracts [85]. The antifungal activities of the aqueous and ethanolic extracts of the leaves of Lawsonia inermis were investigated against different strains of Candida albicans. Compared with aqueous and ethanolic pomegranate peel and seed extracts, Lawsonia inermis leaves extracts showed a higher effect $(20 \mathrm{~mm})$ and the aqueous extracts of henna was more potent than ethanolic extracts [86].

\section{Antiparasitic effects}

The chloroform, ethanol and water extracts of the leaves of Lawsonia inermis $(10,20,50$ and $100 \mathrm{mg} / \mathrm{ml})$ were investigated for anthelmintic effect using adult Eicinia fetida. Lawsonia innermis extracts produced paralytic effect much earlier and the time to death was shorter [63]. The anti-Strongyloides effect of Lawsonia inermis (stems $70 \%$ methanolic extract) was studied in vitro, larvae and free-living females were incubated with different concentrations of Lawsonia $(1,10,100 \mathrm{mg} / \mathrm{ml})$, for different incubation periods (24, 48,72 and $96 \mathrm{~h}$ ). Lawsonia inermis in a concentration of $10 \mathrm{mg} / \mathrm{ml}$ for $24 \mathrm{~h}$ affected the parasite cuticular surface in the form of transverse and longitudinal fissures and transverse depression in comparison to no cuticular change with flubendazole $(100 \mathrm{mg} / \mathrm{ml})$ [87]. The antimalarial activity of henna extract was studied in vitro. The antimalarial activity of petroleum ether extract was $27 \mathrm{mg} / \mathrm{l}$ and ethyl extract was $33 \mathrm{mg} / \mathrm{l}$ against both FcB1-Columbia and FcM29Cameroon strains of $P$. falciparum [32]. A chemically characterized extract and its major constituent were investigated for in vitro antiplasmodial activity on chloroquine-sensitive NF-54 strain. The ethyl acetate extract of leaves ( $\mathrm{IC}_{50} 9.00 \pm 0.68 \mu \mathrm{g} / \mathrm{ml}$ ) and fraxetin (IC50 $19.21 \pm 1.04 \mu \mathrm{M}$ ) were the most effective in in vitro assays and they were further selected for in vivo in Plasmodium berghei infected mice. The administration of the ethyl acetate extract of leaves and fraxetin to the infected mice resulted in significant $(\mathrm{p}<0.05)$ suppression of parasitemia as evidenced by a $70.44 \pm 2.58 \%$ to $78.77 \pm 3.43 \%$ reduction. A two-fold increase in mean survival time, a significant $(\mathrm{p}<0.05)$ reduction in lipid peroxidation and an elevation in glutathione, catalase, and superoxide dismutase were also observed in treated mice. The post-infection treatment also augmented the endogenous antioxidant enzymes compared with infected control [88]. The synergistic anti-leishmanial effect of Peganum harmala and Lawsonia inermis was studied using MTT assay. A significant $(\mathrm{p}<0.01)$ inhibition of promastigotes of $L$. tropica was possessed by both extracts at low and moderate concentrations, the combined extracts revealed a synergistic inhibitory effect in comparison with each one [89]. Constituents of Lawsonia inermis showed antileishmanial (Leishmania tropica) effects. Luteolin was the most potent anti-antileishmanial compound with an $\mathrm{IC}_{50}$ value of $4.15 \mu \mathrm{g} / \mathrm{ml}$ [49]. The antileishmanial effect of Lawsonia inermis methanolic extracts $(0.07,0.15,0.31,0.62,1.25,2.5,5,10 \mathrm{mg} / \mathrm{ml})$ was studied on Leishmania major promastigotes using the MTT assay. Lawsonia inermis methanolic extract inhibited the growth of promastigote forms of L. major in vitro after $72 \mathrm{~h}$ of incubation and showed $\mathrm{IC}_{50}$ of $1.25 \mathrm{mg} / \mathrm{ml}$ [90]. The in vitro antileishmanial activity of the hydroalcoholic extract of Lawsonia inermis was tested on the growth of the promastigotes of Leishmania major. The results showed that Lawsonia inermis extracts reduced the promastigotes number significantly $(\mathrm{p}<0.01)$ [91]. The $90 \%$ ethanolic extract of Lawsonia inermis leaves was investigated for anticoccidial effects against caecal coccidiosis in broilers. Lawsonia inermis leaves extract at a dose of $300 \mathrm{ppm}$ as feed supplement showed good anticoccidial effects, it significantly reduced the lesions and mortality as compared with salinomycin [92]. The antitrypanosomal activity of Lawsonia inermis leaves was investigated in vitro and in vivo. the crude methanolic extract of Lawsonia inermis leaves had in vitro activity against Trypanosoma brucei at concentration of $8.3 \mathrm{mg} / \mathrm{ml}$ while in vivo study revealed that the methanolic extract of Lawsonia inermis leaves ameliorated the disease condition but did not affect the level of parasitaemia and pack cell volume [93]. The ameliorative effect of methanol leaf extract of Lawsonia inermis (125, 250 and $500 \mathrm{mg} / \mathrm{kg}$, orally) was studied in rats infected intraperitoneally with 106 Trypanosoma congolense per $\mathrm{ml}$ of blood. The extract significantly $(\mathrm{p}<0.05)$ reduced levels of parasitaemia at $250 \mathrm{mg} / \mathrm{kg}$, increased PCV $(p>0.05)$ and significantly decreased EOF and MDA. The authors concluded that, in addition to an antitrypanosomal effect of of Lawsonia inermis against T. congolense in rats, it attenuated the trypanosomosis pathology probably via protection of the erythrocyte membrane against trypanosome-induced oxidative damage to the erythrocytes [94]. The lousicidal activity of synthesized Ag NPs was studied against human head louse, Pediculus humanus capitis De Geer (Phthiraptera: Pediculidae), and sheep body louse, Bovicola ovis Schrank (Phthiraptera: Trichodectidae). The average percent mortality for synthesized Ag NPs was 33, 84, 91 , and 100 at $10,15,20$, and $35 \mathrm{~min}$, respectively against $B$. ovis. The maximum activity was observed in the aqueous leaf extract of Lawsonia inermis, $1 \mathrm{mmol}$ AgNO3 solution, and synthesized Ag NPs against $P$. humanus capitis. The findings revealed that Ag NPs possessed the highest anti-lousicidal activity [95]. The larvicidal activity of Lawsonia inermis (4, 40, 400 and 4000 ppm) was studied against, the malaria vector, Anopheles stephensi. The highest toxic effect of Lawsonia inermis was found at $4000 \mathrm{ppm}$ and the lowest at 4 ppm against larval stages I and II. The same result was found against larval stages III and IV. The $\mathrm{LC}_{50}$ and LC90 were 413.8, $3366.3,696.9$ and $3927.7 \mathrm{ppm}$ respectively against larval stages I, II, III and IV stages [96]. The larvicidal effects of the methanolic extracts of 11 medicinal plants were investigated against malaria vector, Anopheles stephensi. The methanolic extract of aerial parts of Lawsonia inermis showed high larvicidal activity with $\mathrm{LC}_{50}$ value of $69.40 \mathrm{ppm}$ [97].

\section{Molluscicidal effects}

Molluscicidal activity of Leaf, bark and seed of Lawsonia inermis was tested against Lymnaea acuminata and Indoplanorbis exustus. Seed powder was more toxic than leaf and bark against I. exustus. Binary combinations of henna seed with Cedrus deodara and Azadirachta indica oil, powdered Allium sativum, or Zingiber officinale rhizome oleoresin revealed more toxicity to snails L. acuminata and I. exustus than their single treatment. The combination with neem oil was also more toxic than their individual components and other combinations [98].

\section{Antioxidant activity}

Antioxidant activity of Lawsonia inermis extracts was studied using DPPH and ABTS. The ethyl acetate extract showed an IC 50 of $29.5 \pm 0.8 \mathrm{mg} / \mathrm{l}$ in DPPH radical scavenging assay and $\mathrm{IC}_{50}$ of $8.6 \pm 0.2$ $\mathrm{mg} / \mathrm{l}$ in ABTS radical scavenging assay. The ethanol extract exhibited an $\mathrm{IC}_{50}$ of $14.1 \pm 0.5 \mathrm{mg} / \mathrm{l}$ in DPPH and $\mathrm{IC}_{50}$ of $6.9 \pm 0.1 \mathrm{mg} / \mathrm{l}$ in ABTS radical scavenging assay. Petroleum ether extract was the less antioxidant extract. The decoction was the most antioxidant extract with $\mathrm{IC}_{50}$ of $13.0 \pm 0.6 \mathrm{mg} / \mathrm{l}$ in DPPH and $\mathrm{IC}_{50}$ of $16.8 \pm 0.7 \mathrm{mg} / \mathrm{l}$ in ABTS radical scavenging assay [32]. The antiradical and DNA protective activity of water extract of Lawsonia inermis leaves were investigated in vitro. The extract quenched DPPH and ABTS cation radicals with $\mathrm{IC}_{50}$ value of $352.77 \mu \mathrm{g} / \mathrm{ml}$ and $380.87 \mu \mathrm{g} / \mathrm{ml}$ respectively. It demonstrated hydroxyl radical scavenging potential of $59.75 \%$ at highest dose $(1000 \mu \mathrm{g} / \mathrm{ml})$ in deoxyribose degradation assay. The results of FRAP assay showed that the extract also possessed significant reducing activity. Extract inhibited hydroxyl radical-induced pBR322 plasmid DNA strand scission, thus conferring DNA protection [99]. The crude extract, 50\% methanol, petroleum ether and ethyl acetate fractions of Lawsonia inermis leaves were investigated for antioxidant activity and their ability to counteract amyloid- $\beta 42(\mathrm{~A} \beta 42)$ aggregation. A new compound with powerful antioxidant and anti-A $\beta 42$ aggregation properties was characterized as 1,2,4-trihydroxynaphthalene-2-0- $\beta$ D-glucopyranoside (THNG) [33]. The antioxidant activity of the 
methanolic extract of leaf of Lawsonia inermis was studied by DPPH free radical scavenging assay. Lawsonia inermis showed antioxidant activity ( IC $_{50}=17.0689 \mu \mathrm{g} / \mathrm{ml}$ ) [100]. The antioxidant effect of hexane, chloroform and methanolic extracts of henna seeds was studied using DPPH and ABTS assay. Methanolic extract showed the higher antioxidant capacity $\left(\mathrm{IC}_{50}=4.6 \mathrm{mg} / \mathrm{l}\right.$ by $\mathrm{DPPH}$ assay and $\mathrm{IC}_{50}=3 \mathrm{mg} / \mathrm{l}$ by ABTS assay). Chloroform and hexane extracts showed no antioxidant activity ( IC $_{50}>100 \mathrm{mg} / \mathrm{l}$ ) [42]. The ethanolic extracts of Lawsonia inermis leaves showed significant scavenging of DPPH free radicals. Maximum scavenging of $79.16 \pm 0.98 \%$ was observed by petroleum ether fraction which was comparable to that of ascorbic acid (78.07.3 $\pm 1.2 \%)$, followed by ethyl acetate fraction $(73.77 \pm 0.97)$ and chloroform fraction $(72.61 \pm 0.98 \%)$, respectively. The total antioxidant capacity was increased with the increasing concentration of samples [101]. The antioxidant activity of the henna seeds extracts was determined by phosphor-molybenum method, DPPH radical scavenging assay, reducing power assay and lipid peroxidation inhibition assay. Ethanol extract, (compared with other extracts: petroleum ether, dichloromethane, and aqueous extracts) showed greater antioxidant activity in all the assays. The activity of the aqueous extract was lesser when compared with that of ethanol extract but greater than petroleum ether and dichloromethane. The amount of phenolics was greater in ethanol $(141.65 \pm 0.29)$ and aqueous $(51.46 \pm 0.44)$ compared with dichloromethane $(4.60 \pm 0.03)$ and petroleum ether extracts (3.72 \pm 0.23$) \mathrm{mg}$ Gallic acid equivalent/g extract [102].

\section{Hepatoprotective activity}

The in vitro antioxidant and in vivo hepatoprotective potential of butanolic fraction of Lawsonia inermis leaves (100, 200 and $400 \mathrm{mg} / \mathrm{kg} \mathrm{bw}$ ) was studied against 2-acetylaminofluorene (2-AAF) induced hepatic damage in male Wistar rats. Butanoic fraction effectively scavenged hydroxyl radicals in deoxyribose degradation assay (IC $50149.12 \mu \mathrm{g} / \mathrm{ml}$ ). It also inhibited lipid peroxidation and caused appreciable reducing potential in FRAP assay. Different concentration of butanoic fraction showed pronounced hepatoprotective effects via decreasing levels of SGOT, SGPT, ALP and lipid peroxidation altered by 2-AAF treatment. It also restored the normal liver architecture as evident from hepatoprotective effect [103]. The hepatoprotective effect of the methanolic extract of Lawsonia inermis leaves (100 and $200 \mathrm{mg} / \mathrm{kg}$ ) was investigated in carbon tetrachloride-induced hepatotoxicity in rats. The doses of the plant extract showed dose-dependent hepatoprotective effect, as evident by the significant reduction $(\mathrm{p}<0.05)$ in serum levels of AST, ALT, ALP, and bilirubin along with the improvement in histopathological liver sections compared to $\mathrm{CCl}_{4}$-treated animals [104]. The hepatoprotective efficacy of lawsone, the major bioactive naphthoquinone present in Lawsonia inermis was studied in RIF-INH exposed HepG2 cells, and RIF-INH induced hepatotoxicity in Wistar rats. Administration of RIF-INH reduced the viability of the HepG2 cells and the treatment with lawsone significantly restored the viability of the cells even at lower concentration $(7.5 \mu \mathrm{M})$, the leakage of transaminases and MDA levels were also significantly reduced by the treatment with lawsone. Treatment with lawsone to the RIF-INH administered animals significantly lowered the serum transaminases and bilirubin, levels and improved the ratio of albumin to globulin [105]. The hepatoprotective activity of the ethanolic extract of the dried leaves of Lawsonia inermis and its crude fractions (petroleum ether, ethyl acetate, butanol and butanone fractions) was evaluated using $\mathrm{CCl}_{4}$ induced hepatotoxicity in mice. The ethanolic extract and its fractions reduced the SGOT, SGPT, SAL activities, total bilirubin content and liver weight compared to control [106]. The hepatoprotective activity of ethanolic extracts of various fractions (ethyl acetate, petroleum ether and chloroform) of Lawsonia inermis leaves was investigated in $\mathrm{CCl}_{4}$-induced hepatitis rats. The extracts at the doses of 200 $\mathrm{mg} / \mathrm{kg}$ orally significantly $(\mathrm{p}<0.05)$ reduced the elevated levels of serum bilirubin, SGPT, SGOT and SALP compared to the $\mathrm{CCl}_{4}$-treated group [101]. The hepatoprotective activity of an ethanol-water (1:1) extract of Lawsonia alba was studied in $\mathrm{CCl}_{4}$-induced liver hepatotoxicity. The results of the effects of the extract on hexobarbitone-induced sleep, BSP clearance, and on certain biochemical parameters indicated its protective role [107]. The antioxidant and hepatoprotective properties of different fractions obtained from the fruits of Lawsonia inermis were investigated against carbon tetrachloride $\left(\mathrm{CCl}_{4}\right)$-induced oxidative stress in rat liver. Several fractions obtained from Lawsonia inermis fruits possessed important antioxidant activity. Ethyl acetate fraction showed the highest antioxidant activity. Pretreatment of rats with ethyl acetate fraction of fruits of Lawsonia inermis at a dose of 250 $\mathrm{mg} / \mathrm{kg}$ bw and gallic acid significantly lowered some serum alanine aminotransferase, aspartate aminotransferase, alkaline phosphatase, and lactate dehydrogenase. Ethyl acetate fraction and gallic acid also caused significant reduction in the hepatic thiobarbituric acid reactive substances and increased antioxidant enzymes (superoxide dismutase, catalase, and glutathione peroxidase) in liver from oxidative stress induced by $\mathrm{CCl}_{4}$ [108].

\section{Central nervous effects}

The psychopharmacological activity of methanolic extract of Lawsonia inermis $(50,100$ and $200 \mathrm{mg} / \mathrm{kg})$ was studied in albino mice using staircase test. The methanolic extract of Lawsonia inermis at $100 \mathrm{mg} / \mathrm{kg}$ drastically augmented the number of steps up in the Staircase with peak activity procured at the dosage of $100 \mathrm{mg} / \mathrm{kg}(37.8 \pm 4.2$ seconds) compared to control $(6.3 \pm 2.2$ seconds). The extract at dosage of $100 \mathrm{mg} / \mathrm{kg}$ notably accelerated the number of steps up with peak effect at the dosage of 100 $\mathrm{mg} / \mathrm{kg}(37.8 \pm 4.2$ seconds) compared to control $(6.3 \pm 2.2$ seconds $)$ [109].

The methanolic extract of Lawsonia inermis was tested for anxiolytic potential using white dark box model in mice. The extract at a dose of $100 \mathrm{mg} / \mathrm{kg}$ ip, exhibited a significant increase in time spent in light area with respect to control animals. The reduction in anxiety behavior, also demonstrated by significant increase in number of entries in the light compartment relative to the dark compartment of the testing apparatus [110]. The effect of acute and chronic administration of aqueous extract of Lawsonia inermis leaves $(100$, 200 and $400 \mathrm{mg} / \mathrm{kg}$ ) was investigated on haloperidol (1 mg/kg, ip) induced catalepsy in albino mice as an animal model for Parkinson's disease (PD). Extract caused significant reduction in the cataleptic scores and increase in SOD activity, the maximum reduction was observed in chronic administration of a dose of $400 \mathrm{mg} / \mathrm{kg}$ bw [24].

The acetone fraction of petroleum ether extract of Lawsonia inermis exhibited prominent nootropic activity, potentiated clonidine induced hypothermia and decreased lithium-induced head twitches. However, the haloperidol-induced catalepsy was not modified [111].

The crude ethanolic extract of Lawsonia inermis $\quad(0.25-2.0 \mathrm{~g} / \mathrm{kg})$ significantly increased pentobarbitone-induced sleeping time in rats. A pure compound was isolated from the chloroform extract (2hydroxy-1,4-naphthaquinone, lawsone), it potentiated significantly the pentobarbitone-induced sleeping time [112].

The chloroform, ethanol and water extracts of the leaves of Lawsonia inermis $(20 \mathrm{mg} / \mathrm{kg}$, bw) were investigated for anticonvulsant activity using electroshock method in mice. Chloroform and ethanol extracts exhibited anticonvulsant activity but more significant activity was recorded for the chloroform extract [63].

In studying the anti-cholinesterase activity of hexane, chloroform and methanolic extracts of henna seeds, the methanol extract inhibited a potent anticholinesterase activity $\left(\mathrm{IC}_{50}=66.6 \mathrm{mg} / \mathrm{l}\right.$ ), while, chloroform and hexane extract eerted no anti-cholinesterase activity ( $\mathrm{IC}_{50}>100 \mathrm{mg} / \mathrm{l}$ ) [42].

\section{Ati-inflammatory, analgesic and antipyretic effects}

The anti-inflammatory effect of methanolic extracts of Lawsonia inermis was determined using acetic acid-induced writhing test in mice. The methanolic leaves extract significantly reduced the chemically induced nociceptive pain stimuli $(p<0.01)$ [113].

In the investigation of anti-inflammatory effects (anti-5-LOX) of hexane, chloroform and methanolic extracts of henna seeds, it appeared that the anti-inflammatory activity of the methanolic extract was superior to that of all tested extracts, with $\mathrm{IC}_{50}$ value of $51 \pm 0.23 \mathrm{mg} / \mathrm{l}$. Chloroform and hexane extracts were inactive as antiinflammatory extracts (IC $50>100 \mathrm{mg} / \mathrm{l}$ ) [42]. 
The aqueous leaves extracts $(50,100,250,500,1000,2000 \mu \mathrm{g} / \mathrm{ml})$ were tested for antiarthritic potential by evaluation of the percentage inhibition of protein denaturation and membrane lysis method. The aqueous extract of Lawsonia inermis revealed antiarthritic activity in a dose dependent manner, its effect was comparable that of diclofenac sodium statistically [114]

The analgesic and anti-inflammatory effects of the mixture of Lawsonia inermis leaves with aqueous extract of Ricinus communis leaves was studied in rats with induced knee osteoarthritis. The knee osteoarthritis was induced by intra-articular injection of mono sodium iodoacetate. The mixture of extracts significantly reduced the knee joint width and volume of the injected paws and also improved foot prints in gait analysis after $3 \mathrm{~d}$ of injection. Analysis of mechanical allodynia after $21 \mathrm{~d}$, hotplate latency test after $10 \mathrm{~d}$, spontaneous movements after $7 \mathrm{~d}$ and in mechanical allodynia after $14 \mathrm{~d}$, showed significant analgesic effects compared to the vehicle group. The formulation also made significant therapeutic histopathological changes on the knee of the rats [115].

The crude ethanolic extract of Lawsonia inermis $\quad(0.25-2.0 \mathrm{~g} / \mathrm{kg})$ produced significant and dose-dependent anti-inflammatory, analgesic, and antipyretic effects in rats. The butanol and chloroform fractions showed more potent anti-inflammatory, analgesic, and antipyretic effects than the crude extracts, the butanolic extract (500 $\mathrm{mg} / \mathrm{kg}$ ) was the most effective in the analgesic test. A pure compound was isolated from the chloroform extract (2-hydroxy-1,4naphthaquinone, lawsone) which possessed significant antiinflammatory, analgesic, and antipyretic activity. The antiinflammatory effect of lawsone $(500 \mathrm{mg} / \mathrm{kg})$ was not significantly different from that of the reference drug, phenylbutazone (100 $\mathrm{mg} / \mathrm{kg}$ ) [112].

The analgesic activity of methanol, petroleum ether and ethyl acetate extracts of Lawsonia inermis leaves (250 and $500 \mathrm{mg} / \mathrm{kg}$, ip) was evaluated by hot-plate and acetic acid-induced writhing methods in mice. All the extract displayed significant analgesic effect $(\mathrm{p}<0.05-0.001)$ in acetic acid and heat-induced pain models in a dose-dependent manner [116].

The synergistic analgesic activities of chloroform extracts of leaves and roots tubers of Lawsonia inermis and Chlorophytum borivilianum was studied in mice using tail immersion and hot plate methods. The results showed that the chloroform extract of both plants significantly produced analgesic activity at the dose level of 200 $\mathrm{mg} / \mathrm{kg}$ bw, and the combination of both extracts showed more analgesic activity as compare to each one [117].

The ethanol extract of the leaf of Lawsonia inermis was examined for analgesic properties using acetic acid-induced writhing in mice. The ethanol extract at a dose of $500 \mathrm{mg} / \mathrm{kg}$ exhibited no significant $(\mathrm{p}<0.3)$ inhibition of writhing reflex ( $28.45 \%$ inhibition) while the inhibition of diclofenac sodium was $82.7 \%$ at a dose of $25 \mathrm{mg} / \mathrm{kg}$ bw [118].

\section{Decubitus ulcers preventing effect and wound and burn healing}

The wound healing activity of the ethanol extract of Lawsonia inermis $(200 \mathrm{mg} / \mathrm{kg} /$ day) was studied in rats using excision, incision and dead space wound models. The extract treated animals showed a high rate of wound contraction $(\mathrm{p}<0.001)$, a decrease in the period of epithelialization $(p<0.001)$, high skin breaking strength $(p<0.001)$, significant increase in the granulation tissue weight $(\mathrm{p}<0.001)$ and hydroxyproline content $(\mathrm{p}<0.05)$ compared with the control group. The extract-treated animals showed $71 \%$ reduction in the wound area when compared with controls. Histological studies of the tissue obtained on day 10 from the extract-treated group showed increased well organized bands of collagen, more fibroblasts and few inflammatory cells when compared with the controls [119].

Plant materials from Adiantum capillus-veneris, Commiphora molmol, Aloe vera, and henna were tested for wound healing. The dried leaves and resins were crumbled into a powder and mixed in equal parts with Vaseline. The mixture was used as an ointment on wounds induced in 60 diabetic and non-diabetic rats. The expression of the Mmp9 gene was decreased significantly $(\mathrm{p}<0.05)$ in diabetic rats after $14 \mathrm{~d}$ with accelerated healing in comparison to nondiabetic rats treated by herbal mixture ointment [120].
Topical henna extract possessed antibacterial, antifungal, and wound healing activity. Henna also improved wound healing in fissures and cracks in diabetic feet. Topical henna prepared by mixing $1 \mathrm{gr}$ of powdered leaves to $10 \mathrm{ml}$ of distilled water and subsequently applied locally and kept wrapped with a dressing for 4-6 $\mathrm{h}$ before washing, provided a long-term barrier against moisture and thus didn't require frequent application [121].

A bioactive gelatin-oxidized starch nanofibers containing Lawsonia inermis (henna) was prepared for treatment of second-degree burn wounds. In vivo studies showed that the nanofibers loaded with henna accelerated wound closure remarkably with the absence of detrimental suppurative reaction at the site of the burn wound. The immune-histochemical stained wound tissue showed that treatment of the burn wound sites with gelatin-oxidized starch-henna reduced the inflammatory response and macrophage numbers significantly [122]

Wound healing potential of different extracts of Lawsonia inermis leaves and lawsone was studied in rat excision and incision wound models. Oral administration and topical application of ethanol extract of henna leaves and lawsone exhibited significant healing response in both wound models. The ethanol extract, as well as lawsone topically, were more effective than their oral uses [123].

The cooling and protecting effects of henna on the prevention of decubitus ulcers were investigated in a randomized clinical trial conducted on 80 patients hospitalized in intensive care units. Patients were randomly allocated into 2 groups of control and intervention. For the intervention group, henna was applied with 15 $\mathrm{cm}$ extent on the patients' sacrum. At the end of the study, 1 patient in the intervention group ( $2.7 \%$ male) and 6 patients in the control group (14.29\% male, $2.85 \%$ female) had developed decubitus ulcers; this difference was significant $(p=.001)$ [124].

\section{Abortificient effect}

The abortificient effect of Lawsonia inermis extract was studied in the pregnant mice. 1 and $10 \mathrm{mg} / \mathrm{kg}$ bw of the hydroalcoholic extract of Lawsonia inermis were injected intraperitoneally into pregnant mice from the first to the seventeenth day of pregnancy. Abortions were observed more often in the Lawsonia inermis treated groups $(p<0.01)$ with significantly higher mean of the serum estrogen $(p<0.01)$ and the significantly lower mean of progesterone level $(\mathrm{p}<0.01)$ [125].

However, the methanolic extract showed a dose-dependent effect in the induction of abortion in mice, rats and guinea pig [126].

\section{Immunomodulatory effect}

The methanolic extract of henna leaves at $1 \mathrm{mg} / \mathrm{ml}$ concentration possessed immunomodulatory evidenced by stimulation of $\mathrm{T}$ lymphocyte proliferative responses. Naphthoquinone obtained from leaves also showed significant immunomodulatory effect $[127,128]$.

\section{Gingivitis healing activity}

The effectiveness of Lawsonia inermis leaves methanol extracts $(62.500,31.250$, and $15.625 \mu \mathrm{g} / \mathrm{ml})$ in healing gingivitis was studied in Sprague Dawley rats with induced artificial inflammation in the mandibular labial gingiva by $10 \% \mathrm{H} 202$. There was no difference in healing between the three concentrations of Lawsonia inermis leaves methanol extract and povidone-iodine, while there were differences among the 3 concentrations. Higher concentration $(62.500 \mu \mathrm{g} / \mathrm{ml})$ can accelerate the inflammatory cells reduction and epithelial connective tissue repair [129]. The effect of Lawsonia inermis leaves infusion in gingivitis healing was studied clinically. Sixty-three gingivitis patients were instructed to rinse with 3 concentrations $(50000,10000$ and $5000 \mu \mathrm{g} / \mathrm{ml})$ of Lawsonia inermis leaves infusion, $0.1 \%$ hexetidine solution, and placebo as control. Bleeding index was decreased in Lawsonia inermis leaves infusion at $10000 \mu \mathrm{g} / \mathrm{ml}$ concentration (80\%), more than hexetidine $0.1 \%$ (76\%) [130].

\section{Antiurolithiatic activity}

The curative and protective effects of the alcoholic extract of Lawsonia inermis bark against ethylene glycol induced urolithiasis and its possible underlying mechanisms were studied in rats. 
Methanolic extract of Lawsonia inermis (MELI) bark (300 and 500 $\mathrm{mg} / \mathrm{kg}$, po) were administered once daily from 15 th day to 28th day as curative regimen and from 1st day to 28th day as a preventive regimen. Treatment with the extract significantly restored all elevated parameters including calcium, phosphate and oxalate in urine and kidney homogenate; and creatinine, uric acid and urea nitrogen in serum compared to the control group. The histopathological study of the kidney also supported the biochemical results [131].

The antiurolithiatic activity of hydroethanolic extract of the leaves of Lawsonia inermis was studied in ethylene glycol with ammonium chloride model in rats. Hydroethanolic extract showed significant antiurolithiatic activity against calcium oxalate type stone. It modulated the levels of serum urea, urea nitrogen, uric acid, creatinine, kidney weight, urine volume, urine $\mathrm{PH}$, urinary total protein, calcium, phosphorus, and magnesium [132].

\section{Antidiabetic and hypolipidemic effects}

The hypoglycemic and hypolipidemic effects of Lawsonia inermis hydroalcoholic extract $(100,200$ and $400 \mathrm{mg} / \mathrm{kg})$ were studied in alloxan-induced diabetic dyslipidemia in rats. The percentage reduction in blood glucose level of Lawsonia inermis hydroalcoholic extract at dose of $400 \mathrm{mg} / \mathrm{kg}$ was $39.08 \%$ on day 21 compared to baseline, which was comparable to glibenclamide (44.77\%) and metformin (46.30\%). The hypoglycemic effect of the extract exhibited significant improvement in lipid profile, plasma albumin, total plasma protein and serum creatinine [133].

The antidiabetic effect of methanolic extracts of Lawsonia inermis was determined by quantitatively determining the maltose from the maltose standard curve. The methanolic leaves extract of the plant significantly inhibited the enzymatic activity of the amylase at $10 \mu \mathrm{g} / \mathrm{m}$ dose (60.97\% compared to untreated, $\mathrm{p}<0.05$ ) [113].

Ethanol extract of Lawsonia inermis leaves ( $400 \mathrm{mg} / \mathrm{kg}$ bw for $21 \mathrm{~d}$ ) significantly decreased mice blood glucose level in alloxan indued diabetes $(\mathrm{p}<0.001)$ compared with control of untreated diabetes [134].

Lawsonia inermis (70\% ethanol extract, $0.8 \mathrm{~g} / \mathrm{kg}$ bw, orally) possessed significant hypoglycaemic and hypolipidaemic activities in alloxan induced diabetic mice. The extract normalizes the concentration of glucose, cholesterol and triglycerides [135].

The effect of $70 \%$ ethanol extract of Lawsonia inermis leaves on glucose, total cholesterol and triglyceride were studied in alloxan induced diabetes in mice. The results showed that the feeding of $0.8 \mathrm{~g} / \mathrm{kg}$ bw of the extract decreased the glucose concentration from $194 \mathrm{mg} / \mathrm{dl}$ to normal condition after $14 \mathrm{~d}$. The total cholesterol concentration decreased from $148.9 \mathrm{mg} / \mathrm{dl}$ to $55.3 \mathrm{mg} / \mathrm{dl}$, while triglyceride concentration decreased from $225.7 \mathrm{mg} / \mathrm{dl}$ to $76.9 \mathrm{mg} / \mathrm{dl}$ [136].

\section{Antiulcer effects}

The antiulcer effects of aqueous, chloroform and ethanol extracts of henna leaves (200 and $400 \mathrm{mg} / \mathrm{kg} \mathrm{bw}$ ) was studied in rats pylorus ligation and aspirin-induced ulcer. In aspirin induced ulcers, the chloroform extract showed significant reduction of ulcers in a dose dependent manner. However, the results showed that aqueous, ethanol and chloroform extract significantly $(p<0.001)$ decreased the volume of gastric acid secretions, free acidity and total acidity and ulcer index [137].

\section{Antidiarrhoeal effects}

The ethanol extract of the leaf of Lawsonia inermis was examined for anti-diarrhoeal properties using the castor oil induced diarrhea model in mice. The ethanol extract at a dose of $500 \mathrm{mg} / \mathrm{kg}$ possessed antidiarrhoeal activity compared to the control group and offered about 1.398 of the mean latent period for the diarrhoeal episode $(p<0.002)$ [118].

\section{Diuretic activity}

The diuretic activity of aqueous and ethanolic extracts (250 and 500 $\mathrm{mg} / \mathrm{kg}$, orally) of Lawsonia inermis leaves was investigate in rats. Both extracts of leaves showed significant diuresis, ethanolic extract showed more activity than aqueous extract. Urine volume in rats treated with aqueous extract of Lawsonia inermis at low and high doses were $4.6 \mathrm{ml}$ and $6.1 \mathrm{ml}$ respectively, while, urine volume in rats treated with ethanolic extract at low and high dose were 7.3 $\mathrm{ml}$ and $9.0 \mathrm{ml}$ respectively. The concentrations of $\mathrm{Na}+, \mathrm{K}+$ and $\mathrm{Cl}-$ in rats treated with aqueous extracts at low dose were 113.8, 66.60 and $127.3 \mathrm{mEq} / \mathrm{l}$ respectively, and high dose $127.8,73.60$ and $155.6 \mathrm{mEq} / \mathrm{l}$ respectively, while, the concentrations of $\mathrm{Na}^{+}$, $\mathrm{K}^{+}$and $\mathrm{Cl}-\mathrm{in}$ rats treated with ethanolic extracts at low dose were $120.5,71.20$ and $147.5 \mathrm{mEq} / \mathrm{l}$ respectively, and high dose 136.2 , 89.13 and $170.5 \mathrm{mEq} / \mathrm{l}$ respectively [138].

\section{Anticancer effects}

Lawsone and juglone inhibited the growth of HCT-15 (human colon cancer cells) by blocking the S-phase of cell cycle. Lawsone was used as starting compound in the synthesis of many anticancer drugs (atovaquone, lapachol and dichloroallyl lawsone).

Amino-derivatives of lawsone and lapachol were found to be cytotoxic against Ehrlich carcinoma and human K562 (leukemia cells). Allyl-amine derivatives of lawsone and lapachol were found potent cytotoxic with an $\mathrm{IC}_{50}$ values of 23.89 and $16.94 \mu \mathrm{M}$ respectively. Dichloroallyl lawsone, an analog of the lapachol, and acivicin inhibited the biosynthesis of nucleotide and showed anticancer activity in experimental tumor models [139-142].

The anticancer effect of total methanolic extract of Lawsonia inermis and octreotide was studied in hepatocellular carcinoma induced by nitrosamine in mice. Methanolic extract of Lawsonia inermis and octreotide treatment possessed effective chemopreventive action due to their ability to alleviate oxidative stress, desensitizing cellular growth receptor to SST [143].

Quinones (arbutin in the benzoquinone group, juglone and lawsone in the naphthaquinone group, alizarin, emodin, 1,8-dihydroxyanthraquinone, and anthraquinone in the anthraquinone group, and xanthone) were studied for their growth inhibitory effect on cultured HCT-15 cells derived from human colon carcinoma. Anthraquinones and naphthaquinones used in these experiments were more effective than the monocyclic quinone.

The $50 \%$ suppression dose was less than $12.5 \mu \mathrm{g} / \mathrm{ml}$ for them. Flow cytometric histograms revealed a specific pattern; lawsone and juglone in the naphthaquinone group and alizarin and 1,8dihydroxy-anthraquinone in the anthraquinone group blocked mainly the $\mathrm{S}$ phase, and emodin in the anthraquinone group blocked the G1 to S phase of the cell cycle [142].

The cytotoxicity of fifteen compounds isolated from the flower of Lawsonia inermis was studied against four cancer cell lines (MCF-7, Hela, HCT-116, and HT-29) using MTT assay. The $\mathrm{IC}_{50}$ values of two of them against MCF-7, Hela, HCT-116, and HT-29 were $(2.24,1.42,24.29$, and $7.02 \mu \mathrm{M})$ and $(6.1,2.44,5.58$, and $10.21 \mu \mathrm{M})$ respectively. They possessed stronger inhibitory activities than the positive control 5fluorouracil $\left(\mathrm{IC}_{50}=7.34,11.50,36.17,18.83 \mu \mathrm{M}\right)$ against the four tested cell lines [144]. The growth inhibition of various cancer cell lines was achieved to the varying extent when exposed to the water extract of Lawsonia inermis leaves. The activity was promising against colon cancer COLO-205 cells (GI50 $121.03 \mu \mathrm{g} / \mathrm{ml}$ ) [99].

The anticancer effect of hexane, chloroform and methanolic extracts of henna seeds was studied against colon cancer cell line HTC-116. Chloroform seed extract showed the best cytotoxic effect with an $\mathrm{IC}_{50}$ value of $45 \mathrm{mg} / \mathrm{l}$, while, hexane and methanol extracts possessed low activity (IC 50 value $>100 \mathrm{ug} / \mathrm{ml}$ ) [42].

The anti-cancer efficacy of Lawsonia inermis leaves was studied in Ehrlich ascites tumour bearing mice. Administration of $10 \mathrm{mg} / \mathrm{kg}$ bw of Lawsonia inermis to tumour bearing-mice increased the mean survival period of tumor-bearing mice. Lawsonia inermis also caused significant $(\mathrm{p}<0.05)$ reduction in the total number of tumor cells. The diameters of the gluteal solid tumor mass were higher on the 12th day in animals given water when compared with the mice receiving Lawsonia inermis extract $[145,146]$.

Henna extracts showed activity against human breast cancer cells (MCF7), MIC for the ethyl acetate extract was $(27 \mathrm{mg} / \mathrm{l})$ and petroleum extract was $(22 \mathrm{mg} / \mathrm{l})$ [32]. 
The antitumor effect of ethanol extract of root of Lawsonia inermis $(180 \mathrm{mg} / \mathrm{kg}$ of bw for $15 \mathrm{~d})$ was investigated against Dalton's lymphoma ascites (DLA) bearing mice. Treatment with Lawsonia inermis extract improved the liver and kidney function and rearranges more or less normal architecture. The extract also increased the number of the WBC count, platelets, lymphocytes, the pathophysiological marker enzyme and lipid profile and decreased the number of the RBC count, hemoglobin content, monocytes, the enzymic and non enzymic antioxidants [147].

The cytotoxic effect of the extracts of Lawsonia inermis was studied against human colon cancer cell lines (Caco-2), liver cancer cell lines (HepG2), hormone-dependent breast cancer cell lines (MCF-7) and hormone-independent breast cancer cell lines (MDA-MB-231) and Chang Liver cell lines using MTT assay. The chloroform extract of henna was active against human colon cancer cell lines (Caco-2) and liver cancer cell lines (HepG2) with an $\mathrm{IC}_{50}$-value of 25.1 and 28 $\mu \mathrm{g} / \mathrm{ml}$, respectively. The cytotoxic mechanism was studied by determining the effect of the extract on the c-myc gene expression. It caused down-regulation of c-myc expression [148].

The effect of extract and essential oil of henna on the apoptotic phenomena was studied in a human liver cancer cell lines, HepG2. Henna induced apoptosis in HepG2 cell lines, many apoptotic bodies, DNA fragmentation and chromatin condensation were observed in the treated groups through the fluorescence microscope and confocal laser scanning microscope [149].

The effect of aqueous extract of Lawsonia inermis against the development of cancer was studied in Ehrlich ascites cells in mie. The longest life period and decreasing of total number of cancer cell were detected on the group which was given $10 \mathrm{mg} / \mathrm{kg} /$ day Lawsonia inermis aqueous extract [145].

The essential oil from the leaves of Lawsonia inermis exhibited strong cytotoxicity on HepG2 with an $\mathrm{IC}_{50}$ value of $24 \mu \mathrm{g} / \mathrm{ml}$ in MTT test [39].

The anticarcinogenic potential of 200 and $400 \mathrm{mg} / \mathrm{kg}$ bw of $80 \%$ ethanolic extract of the fresh leaves of Lawsonia inermis was studied using benzo (a) pyrene-induced forestomach and 7,12 dimethylbenz (a)anthracene (DMBA)-initiated and croton oil-promoted skin papilloma genesis. The chemopreventive response was measured by the average number of papillomas per mouse (tumor burden) as well as percentage of tumor-bearing animals and tumor multiplicity. There was a significant inhibition of tumor burden in both studied tumor model systems $(\mathrm{p}<0.01$ to $\mathrm{p}<0.001)$. Tumor incidence was also reduced by both doses in both the model systems [150].

The inhibitory effect of Lawsonia inermis leaf extract and lawsone on the Epstein-Barrvirus early antigen (EBV-EA) activation induced by the tumor promoter 12-0-tetradecanoylphorbol-13-acetate (TPA) was investigated in Raji cells. Both showed a profound inhibition $(>88 \%)$ of EBV-EA activation. In the in vivo two-stage mouse skin carcinogenesis study using UV-B radiation for initiation and TPA for tumor promotion, oral feeding of henna $(0.0025 \%)$ in drinking water decreased tumor incidence by $66 \%$ and multiplicity by $40 \%$ compared to the positive control at $10 \mathrm{w}$ of treatment. Orally fed lawsone $(0.0025 \%)$ decreased tumor incidence by $72 \%$ and multiplicity by $50 \%$. The tumor inhibitory trend continued throughout the $20 \mathrm{w}$ test period. Similar antitumor activities were observed when henna $(0.5 \mathrm{mg} / \mathrm{ml})$ was applied topically on the back skin in the UV-B initiated, TPA promoted and peroxynitrite initiated, TPA promoted mouse skin, carcinogenesis models. Topically applied lawsone $(0.015 \mathrm{mg} / \mathrm{ml})$ also exhibited similar protection against tumor formation in the 7, 12-dimtehylbenz (a) anthracene-induced and TPA promoted skin cancer in mice [151].

The methanolic extract of Lawsonia inermis possessed significant inhibitory effect toward melanogenesis in B16 melanoma 4A5 cells. Luteolin, quercetin, and $( \pm)$-eriodictyol isolated from the methanolic extract, showed stronger inhibitory activity. The methanolic extract, luteoloside and spiraeoside, showed antiplasmin activity, which was played a key role in UV-stimulated melanogenesis in human skin [152].
Henna extract $(20 \mu \mathrm{g} / \mathrm{ml})$ was screened for in vitro photocytotoxic activity by means of a cell viability test using a human leukaemia cell line HL60. Lawsonia inermis extract was able to reduce the in vitro cell viability by more than $50 \%$ when exposed to $9.6 \mathrm{~J} / \mathrm{cm} 2$ of a broad spectrum light [153].

\section{Other effects}

The ethanolic extract of Lawsonia inermis leaves and lawsone possessed an $\mathrm{IC}_{50}$ value of 64.87 and $48.6 \mu \mathrm{g} / \mathrm{ml}$ trypsin inhibitory activity, respectively [154].

Compounds, lawsoinermone, (E)-methyl 3-(4-hydroxyphenyl) acrylate, (E)-ethyl 3-(4-hydroxyphenyl)acrylate, caffeoyl alcohol, 2hydroxy-1,4-naphthoquinone and 1,4-naphthoquinone isolated from Lawsonia inermis were evaluated for inhibition of nitric oxide production in LPS-stimulated product of nitrite in RAW 264.7 cell, they showed $\mathrm{IC}_{50}$ values of $6.12,16.43,18.98,9.30,9.30$ and 14.90 $\mu \mathrm{g} / \mathrm{ml}$, respectively [34].

\section{Side effects and toxicity}

The aqueous extract of Lawsonia inermis was found to be safe up to $2 \mathrm{~g} / \mathrm{kg}$ bw orally in mice. After $24 \mathrm{~h}$ there was no mortality and signs of toxicity $[24,105]$. The minimum lethal dose of ethanol-water (1:1) extract of henna was greater than $2 \mathrm{~g} / \mathrm{kg}$ bw orally in mice [107].

The toxicity of the aqueous root extract of Lawsonia inermis (200, $400,800,1200$ and $1600 \mathrm{mg} / \mathrm{kg} \mathrm{bw}$, ip) was investigated in rats. Dizziness, loss of appetite, partial paralysis, temporary amnesia and spontaneous abortion in the pregnant females, were recorded in rats treated with $800-1600 \mathrm{mg} / \mathrm{kg}$ bw. Rats received $200-400 \mathrm{mg} / \mathrm{kg}$ bw remained active and healthy. No mortality was recorded in all doses. The results indicated delayed toxicity after intraperitoneal administration of the extract at various concentrations $[79,155]$.

In acute toxicity study, a volume of $0.1 \mathrm{ml}$ of the test substance (approximately $58 \mathrm{mg}$ ) was instilled into the conjunctival sac of the right eye of each of 3 New Zealand white rabbits. Transient inflammation of the iris and moderate conjunctival irritation were observed up to a maximum of 48 and $72 \mathrm{~h}$. Lawsonia inermis was slightly and transiently irritating to the eyes of New Zealand white rabbits. Lawsonia inermis exhibited no potential to induce dermal sensitization in Guinea pigs. On the other hand, no skin findings were observed on the tested skin area of any of the volunteers at any time during the $3 \mathrm{w}$ of the induction phase and at challenge after a one week rest period. However, it was shown that lawsone penetrated through the pigskin in vitro. After exposure of $30 \mathrm{~min}$ and a follow-up period of $72 \mathrm{~h}$, about $0.28 \%$ of the applied dose of lawsone was penetrated and $0.06 \%$ remained in the skin. The respective absolute skin penetration rate was $703 \mathrm{ng} / \mathrm{cm}^{2}$. In using of radioactive of test substance, the mean percutaneous absorption of the test substance amounted to $0.20 \%$ of the administered radioactivity after $72 \mathrm{~h}$, corresponding to an absolute absorption of $1.70 \mu \mathrm{g} / \mathrm{cm}^{2}$. A 13-week oral toxicity study was conducted in rats with a $0.5 \%$ aqueous methylcellulose solution of henna administered once daily by gavage. The treated animals received the test substance corresponding to daily dosage of 40,200 and 1000 $\mathrm{mg} / \mathrm{kg}$ bw. No mortality was observed during the study. In the high dose group, animals occasionally presented signs of poor clinical condition: loud breathing, piloerection and ptyalism. Brown urine was noted in all males and females, accompanied by a brown tail in some animals. All clinical signs were reversible after 4-weeks recovery period, except for brown-coloured tail. Henna was tested for mutagenicity, it did not induce bacterial (Salmonella typhimurium strains TA98, TA100, TA1535, TA1537 and TA1538) and mammalian cell gene mutation. Henna was administered by daily gavage to 100 pregnant female rats on day 6 through 15 of gestation at the dose levels of 40,200 and $1000 \mathrm{mg} / \mathrm{kg} /$ day bw. No clinical signs, no abortions and no mortalities were recorded in any female of any group during the study. A very slight $(<10 \%)$ but statistically significant decrease of body weight gain and food consumption was observed in the dams receiving $1000 \mathrm{mg} / \mathrm{kg} /$ day. Pre and postimplantation loss, fetal body weight and sex-ratio were similar between control and all treated groups. At the external examination, 
no treatment-related anomalies or malformations were observed [156].

The toxic effect of aqueous extract of Lawsonia inermis seeds was studied in rats. $78.57 \mathrm{mg} / \mathrm{kg}$ orally, of the extract for $4 \mathrm{w}$, caused body weight gain, significant decrease on hematological parameters and potassium concentration, significant increase in the AST, ALP, total protein, albumin and urea concentrations with no histopathological changes. 78.57, 392 and $785.7 \mathrm{mg} / \mathrm{kg} /$ day orally for $1 \mathrm{w}$, increased AST, ALP and total protein concentrations. $785.7 \mathrm{mg} / \mathrm{kg} /$ day of the extract increased the ALT activity and decreased potassium concentration. 78.57 and $785.7 \mathrm{mg} / \mathrm{kg} /$ day of the extract increased urea and cholesterol concentrations, while 392 and $785.7 \mathrm{mg} / \mathrm{kg} /$ day of the extract induced hepatocytic necrosis, dilatation of the renal tubules and desquamation of the intestinal epithelium [157].

The safety of 500 and $1000 \mathrm{~g} / \mathrm{kg}$ dose of Lawsonia inermis ethanolic seeds extracts was studied in mice. The acute dose of $500 \mathrm{mg}$ and $1000 \mathrm{mg} / \mathrm{kg}$ caused no death in animals after $24 \mathrm{~h}$, and no signs of change in feeding, behavior, diarrhea or loss of fur were observed. WBC, RBC haemoglobin and platelets count were minimally affected. Serum $\mathrm{Na}, \mathrm{K}$, creatinine and urea were not deviated from control. Liver enzymes, protein, blood glucose and lipids profile were not affected by chronic administration of henna extract. However a slight but significant elevation in AST was recorded in the high dose group. Post mortem examination showed no signs of toxicity [158].

The teratogenic effects of 10 and $100 \mathrm{mg} / \mathrm{kg}$ bw, ip, of $80 \%$ ethanol extract of the aerial organs of Lawsonia inermis (for $7 \mathrm{~d}$ ) were studied in mice. Both doses of the extract caused significant decrease in embryos' height and weight in comparison with the control $(\mathrm{p}<0.001)$. However, no significant difference was observed between 10 and $100 \mathrm{mg} / \mathrm{kg}$ of the extract in embryos' height and weight. Skeletal abnormalities including rib and parietal bone abnormalities, anencephaly and exencephaly of embryos were recorded in both Lawsonia inermis treated groups with different frequencies [43].

A case of acute kidney injury was recorded in $34 \mathrm{y}$ old man with G6PD deficiency from Yangon, Myanmar, after ingesting a herbal remedy of boiled henna leaves. He developed hemoglobinuria, and he underwent 5 sessions of hemodialysis. His condition improved within $7 \mathrm{w}$ with full recovery [159].

\section{AUTHORS CONTRIBUTIONS}

All the author have contributed equally

\section{CONFLICT OF INTERESTS}

\section{Declare none}

\section{REFERENCES}

1. Al-Snafi AE. Chemical constituents and pharmacological activities of milfoil (Achillea santolina)-a review. Int J Pharm Tech Res 2013;5:1373-7.

2. Al-Snafi AE. The Pharmaceutical importance of Althaea officinalis and Althaea rosea: a review. Int J Pharm Tech Res 2013;5:1387-5.

3. Al-Snafi AE. The pharmacology of Anchusa italica and Anchusa strigosa-a review. Int J Pharm Pharm Sci 2014;6:7-10.

4. Al-Snafi AE. The pharmacological importance of Anethum graveolens-a review. Int J Pharm Pharm Sci 2014;6:11-3.

5. Al-Snafi AE. The chemical constituents and pharmacological importance of Carthamus tinctorius-an overview. J Pharm Biol 2015;5:143-66.

6. Al-Snafi AE. The chemical constituents and pharmacological importance of Chrozophora tinctoria. Int J Pharm Rev Res 2015;5:391-6.

7. Al-Snafi AE. The pharmacology of Crocus sativus-a review. IOSR J Pharm 2016;6:8-38.

8. Al-Snafi AE. The medical importance of Cydonia oblonga-a review. IOSR J Pharm 2016;6:87-99.

9. Al-Snafi AE. Pharmacology and therapeutic potential of Euphorbia hirta (Syn: Euphorbia pilulifera)-a review. IOSR J Pharm 2017;7:7-20.

10. Al-Snafi AE. Glycyrrhiza glabra: a phytochemical and pharmacological review. IOSR J Pharm 2018;8:1-17.
11. Al-Snafi AE. Chemical constituents and pharmacological activities of Gossypium herbaceum and Gossypium hirsutum-a review. IOSR J Pharm 2018;8:64-80.

12. Al-Snafi AE. Chemical constituents and pharmacological effect of Inula graveolens (Syn: Dittrichia graveolens)-a review. Indo Am J Pharm Sci 2018;5:2183-90.

13. Al-Snafi AE. Chemical constituents, nutritional, pharmacological and therapeutic importance of Juglans regia-a review. IOSR J Pharm 2018;8:1-21.

14. Al-Snafi AE. Medical importance of Juniperus communis-a review. Indo Am J Pharm Sci 2018;5:1792-979.

15. Al-Snafi AE. Pharmacological and therapeutic importance of Hibiscus sabdariffa-a review. Int J Pharm Res 2018;10:451-75.

16. The plant list, a working list of all plant species, Lawsonia inermis. Available from: http://www.theplantlist.org/tpl/record/kew-2353863. [Last accessed on 08 Apr 2019]

17. ITIS report, Lawsonia inermis. Available from: https://www.itis.gov/servlet/SingleRpt/SingleRpt?search_topi $\mathrm{c}=\mathrm{TSN}$ andsearch_value $=503345 \#$ null. [Last accessed on $08 \mathrm{Apr}$ 2019]

18. U. S. National Plant Germplasm System, Lawsonia inermis. Available from: https://npgsweb.ars-grin.gov/gringlobal/ taxonomydetail.aspx?21699. [Last accessed on 08 Apr 2019]

19. Boubaya A, Marzougui N, Ben Yahia L, Ferchichi A. Chemical diversity analysis of Tunisian Lawsonia inermis L. populations. Afr J Biotechnol 2011;10:4980-87.

20. Zumrutdal E, Ozaslan M. A miracle plant for the herbal pharmacy; henna (Lawsonia inermis). Pharmacology 2012;896:483-9.

21. Afzal M, Al-Oriquat, Al-Hussan JM, Mohammed N. Flavone glycosides from Lawsonia inermis. Heterocycle 1980;14:1973-6.

22. Jain VC, Shah DP, Sonani NG, Dhakara S, Patel NM Pharmacognostic and preliminary phytochemical investigation of Lawsonia inermis L leaf. Rom J Biol Plant Boil 2010;55:127-33.

23. Trease GE, Evans WC. Pharmacognosy. 14th ed. London: Saunders Company Ltd; 1996. p. 246-98.

24. Shastry CS, Kiran UP, Aswathanarayana BJ. Effect of acute and chronic administration of the aqueous extract of Lawsonia inermis leaves on haloperidol induced catalepsy in albino mice. Res J Pharm Biol Chem Sci 2012;3:1107-16.

25. Borade AS, Kale BN, Shete RV. A phytopharmacological review on Lawsonia inermis (Linn). Int J Pharm Life Sci 2011;2:536-41.

26. Mahmoud ZF, Abdel Salam NA, Khafagy SM. Constituents of henna leaves-Lawsonia inermis L growing in egypt. Fitoterapia 1980;51:153-5.

27. Nakhala AM, Zakin N, Mahrous TS, Ghali M, Youssef AM. Isolation and identification of four aromatic compounds from henna leaves. Chem Microbial Technol Lebenson 1980;6:103-5.

28. Afzal M, Al-Oriqual G, Al-Hussan JM, Mohammed N. Isolation of 1,2-dihydroxy-4-glucosyloxynaphthalene from Lawsonia inermis. Heterocycle 1984;22:813-6.

29. Dzhuraev KS, Nuraliev YN, Kurbanov M, Akhmedova LF, Abyshev AZ. Leaf coumarins of Lawsonia inermis grown in tadzhikistan. Rastit Resur 1982;18:377-9.

30. Sharma RK, Goel A, Bhatia AK. Antityphoid activity and phytochemical screening of different extracts of $L$. inermis plant leaves. Int J Curr Res 2016;8:37539-42.

31. Oda Y, Nakashima S, Kondo E, Nakamura S, Yano M, Kubota $\mathrm{C}$, et al. Comparison of lawsone contents among Lawsonia inermis plant parts and neurite outgrowth accelerators from branches. J Nat Med 2018;72:890-6.

32. Babili FE, Bouajila J, Valentin A, Chatelain C. Lawsonia inermis: Its anatomy and its antimalarial, antioxidant and human breast cancer cells MCF7 activities. Pharm Anal Acta 2013;1:203.

33. Dhouafli Z, Ben Jannet H, Mahjoub B, Leri M, Guillard J, Saidani Tounsi $\mathrm{M}$, et al. 1,2,4-trihydroxynaphthalene-2-O- $\beta$-Dglucopyranoside: a new powerful antioxidant and inhibitor of A 342 aggregation isolated from the leaves of Lawsonia inermis. Nat Prod Res 2017;29:1-9.

34. Yang CS, Chen JJ, Huang HC, Huang GJ, Wang SY, Sung PJ, et al. New benzenoid derivatives and other constituents from Lawsonia inermis with inhibitory activity against NO production. Molecules 2017;22:936-44. 
35. Jacob PP, Saral AM. Two harmala alkaloids from Lawsonia inermis seeds. Chem Nat Compd 2013;49:780.

36. Hien DT, Huong TT, Cuong NX, Thao NP, Nam NH, Dat NT, et al. Triterpenoid constituents from Lawsonia inermis. J Sci Technol 2010;78A:22-6.

37. Kidanemariam TK, Tesama TK, Asressu KH, Boru AD. Chemical investigation of Lawsonia inermis L leaves from Afar Region, Ethiopia. Oriental J Chem 2013;29:1129-34.

38. Oyedeji OA, Ekundayo 0, Koenig WA. Essential oil composition of Lawsonia inermis L. leaves from Nigeria. J Essent Oil Res 2005;17:403-4.

39. Rahmat A, Edrini S, Ismail P, Yap Yun Hin T, Abu Bakar MF. Chemical constituents, antioxidant activity and cytotoxic effects of essential oil from Stobilan thescrispus and Lawsonia innernis. J Biol Sci 2006;6:1005-10.

40. Najar B, Pistelli L. Essential oil composition of Lawsonia inermis leaves from Tunisia. Am J Essential Oils Nat Prod 2017;5:7-11.

41. Hasan KM, Yesmin S, Akhter SF, Paul S, Sarker S, Islam A, et al. Hepatoprotective potentiality of various fractions of ethanolic extracts of Lawsonia Inermis (henna) leaves against chemicalinduced hepatitis in rats. Biochem Mol Biol 2016;1:17-22.

42. Chaibi R, Drine S, Ferchichi A. Chemical study and biological activities of various extracts from Lawsonia inermis (Henna) seeds. Acta Medica Mediterranea 2017;33:981-6.

43. Jafarzadeh L, Seifi N, Shahinfard N, Sedighi M, Kheiri S, Shirzad H, et al. Antioxidant activity and teratogenicity evaluation of Lawsonia inermis in BALB/c mice. J Clin Diagnostic Res 2015;9:1-4.

44. Takeda Y, Fatope MO. New phenolic glucosides from Lawsonia inermis. J Nat Prod 1988;51:725-9.

45. Cuong NX, Nhiem NX, Thao NP, Nam NH, Dat NT, Anh Hle T, et al. Inhibitors of osteoclastogenesis from Lawsonia inermis leaves. Bioorg Med Chem Lett 2010;20:4782-4.

46. Rajeswari J, Rani S. Isolation, structural elucidation of flavonoid constituents from Lawsonia inermis linn. Der Pharm Lett 2016;8:79-84.

47. Cuong NX, Thao NP, Nam NH, Dat NT, Anh HT, Huong LM, et al. Flavonoid constituents from Lawsonia inermis. J Sci Technol 2010;78A:27-30.

48. Yang CS, Chen JJ, Huang HC, Huang Gj, Wang SY, Chao LK, et al. New flavone and eudesmane derivatives from Lawsonia inermis and their inhibitory activity against NO production. Phytochem Lett 2017;21:123-7.

49. Iqbal K, Iqbal J, Staerk D, Kongstad KT. Characterization of antileishmanial compounds from Lawsonia inermis L. leaves using semi-high resolution antileishmanial profiling combined with HPLC-HRMS-SPE-NMR. Front Pharmacol 2017;8:337.

50. Bhardwaj DK, Murari R, Seshadri TR, Singh R. Lacoumarin from Lawsonia inermis. Phytochemistry 1976;15:1789.

51. Yang CS, Huang HC, Wang SY, Sung PJ, Huang GJ, Chen JJ, et al. New diphenol and isocoumarins from the aerial part of Lawsonia inermis and their inhibitory activities against NO production. Molecules 2016;21:E1299.

52. Sharma RK, Goel A. Identification of phytoconstituents in Lawsonia inermis Linn. leaves extract by GC-MS and their antibacterial potential. Pharmacogn J 2018;10:1101-8.

53. Wagini NH, Soliman AS, Abbas MS, Hanafy YA, El-Saady MB. Phytochemical analysis of Nigerian and Egyptian henna (Lawsonia inermis L) leaves using TLC, FTIR and GCMS. Plant 2014;2:27-32.

54. Mengoni T, Peregrina DV, Censi R, Cortese M, Ricciutelli M, Maggia $\mathrm{F}$, et al. SPME-GC-MS analysis of commercial henna samples (Lawsonia inermis L). Nat Prod Res: Formerly Nat Prod Lett 2015;30:268-75.

55. Yusuf M. Phytochemical analysis and antibacterial studies of Lawsonia inermis leaves extract. J Chem Pharm Res 2016;8:571-5.

56. Bich DH, Chung DQ, Chuong BX, Dong NT, Dam DT, Hien PV, et al. Medicinal plants and animals of vietnam. Hanoi Sci Technol Publisher 2004; II:130-3.

57. Al-Saimary I. Antistaphylococcal activity of henna extracts Lawsonia inermis L (Lythraceae). J Microbiol 2015;1:8-11.

58. Akter A, Neela A, Khan MSI, Islam S, Alam F. Screening of ethanol, petroleum ether and chloroform extracts of medicinal plants, Lawsonia inermis $\mathrm{L}$ and Mimosa pudica $\mathrm{L}$ for antibacterial activity. Indian J Pharm Sci 2010;72:388-92.
59. Muhammad HS, Muhammad S. The use of Lawsonia inermis linn (henna) in the management of burn wound infections. Afr J Biotechnol 2005;4:934-7.

60. Aicha L, Rachid D, Abed A. Antibacterial activity and anti-biofilm formation of henna (Lawsonia inermis) extracts against Pseudomonas aeruginosa. J Appl Environ Biol Sci 2017;7:92-104.

61. Kannahi M, VinothaInt K. Antimicrobial activity of Lawsonia inermis leaf extracts against some human pathogens. J Curr Microbiol Appl Sci 2013;2:342-9.

62. Yang JY, Lee HS. Antimicrobial activities of active component isolated from Lawsonia inermis leaves and structure-activity relationships of its analogues against food-borne bacteria. J Food Sci Technol 2015;52:2446-51.

63. Wadekar JB, Pawar PY, Nimbalkar VV, Honde BS, Jadhav PR, Nale SB. Anticonvulsant, anthelmintic and antibacterial activity of Lawsonia inermis. J Phytopharmacol 2016;5:53-5.

64. Al-Rubiay KK, Jaber NN, Al-Mhaawe BH, Alrubaiy LK. Antimicrobial efficacy of henna extracts. Oman Med 2008;23:253-6.

65. Al-Daamy AAK, Abdul Hassan A, Mahmood A. Study of antibacterial activity of Lawsonia inermis leaf extract. J Contemp Med Sci 2016;2:103-6.

66. Habbal OA, Al-Jabri AA, El-Hag AH, Al-Mahrooqi ZH, Al-Hashmi A. In vitro antimicrobial activity of Lawsonia inermis linn (henna). A pilot study of omani henna. Saudi Med J 2005;26:69-72.

67. Musa AE, Selv AT, Vindhan RA, Madhan B, Fathima A, Rao JR, et al. Evaluation of antimicrobial activity of Lawsonia inermis (henna) against microbial strains isolated from goat skin/leather. JALCA 2011;106:170-5.

68. Malekadeh F. Antimicrobial activity of Lawsonia inermis L. Appl Microbiol 1968;16:663-4.

69. Bhuvaneswari K, Poongothai SG, Kuruvilla A, Appala Raju B. Inhibitory concentrations of Lawsonia inermis dry powder for urinary pathogens. Indian J Pharmacol 2002;34:260-3.

70. Arun P. In vitro antibacterial activity of Lawsonia inermis (henna) leaves. PhD thesis, Educational and Research Institute University, Chennai; 2010.

71. Saadabi MAA. Evaluation of Lawsonia inermis linn. (Sudanese henna) leaf extracts as an antimicrobial agent. Res J Biol Sci 2007;2:419-23.

72. Habbal O, SHasson S, AHl-Hag AH, Al-Mahrooqi Z, Al-Hashmi N, Al-Bimani Z, et al. Antibacterial activity of Lawsonia inermis linn (henna) against Pseudomonas aeruginosa. Asian Pac J Trop Biomed 2011;1:173-6.

73. Sarojini N, Kanti CC, Manjari SA, Kumari SU, Priyanka J. In vitro antibacterial activities of Lawsonia inermis leaf extracts. Int Res J Pharm 2012;3:195-7.

74. Abdul Hamza B, ALzubedy H, Omar S, Al-hamdany M, Kwater R, Al-Kazaly $\mathrm{M}$, et al. Biological effect of Lawsonia inermis plant. Al-Mustansiriyah J Sci 2016;27:1-5.

75. Al-Mehna BMM, Kadhum EAH. Effect of Lawsonia inermis extract on the pathological changes of skin infection by Streptococcus pyogens in lab mice. Al-Qadisiya J Vet Med Sci 2011;10:45-53.

76. Jeyaseelan EC, Jenothiny S, Pathmanathan MK, Jeyadevan JP. Antibacterial activity of sequentially extracted organic solvent extracts of fruits, flowers and leaves of Lawsonia inermis L from Jaffna. Asian Pac J Trop Biomed 2012;2:798-802.

77. Elmanama AA, Alyazji AA, Abu Gheneima NA. Antibacterial, antifungal and synergistic effect of Lawsonia inermis, Punica granatum and Hibiscus sabdariffa. Annals of Alquds Med 2011;7:33-41.

78. Sujanamulk B, Chintamaneni R, Chennupati A, Nahar P, Chaluvadi RS, Vemugunta R, et al. Evaluation of antifungal efficacy of ethanolic crude lawsone and listerine mouthwash in onc ontrolled diabetics and denture wearers-a randomized clinical trial. J Clin Diagn Res 2016;10:ZC90-95.

79. Mudi SY, Ibrahim H, Bala MS. Acute toxicity studies of the aqueous root extract of Lawsonia inermis linn in rats. J Med Plant Res 2011;35:5123-6.

80. Mardani M, Badiee P, Gharibnavaz M, Jassebi A, Jafarian $\mathrm{H}$, Ghassemi F. Comparison of anti-candida activities of the ancient plants Lawsonia inermis and Ziziphus spinachristi with 
antifungal drugs in Candida species isolated from oral cavity. J Conserv Dent 2018;21:359-62.

81. Ravichandran S, Muthuraman S. Examining the anti-candidal activity of 10 selected Indian herbs and investigating the effect of Lawsonia inermis extract on germ tube formation, protease, phospholipase, and aspartate dehydrogenase enzyme activity in Candida albicans. Indian J Pharmacol 2016;48:47-52.

82. Yaralizadeh M, Abedi P, Namjoyan F, Fatahinia M, Nezamiv, Chegini S. A comparison of the effects of Lawsonia inermis (Iranian henna) and clotrimazole on Candida albicans in rats. J Mycol Med 2018;28:419-23.

83. Gozubuyuk GS, Aktas E, Yigit N. An ancient plant Lawsonia inermis (henna): Determination of in vitro antifungal activity against dermatophytes species. J Mycol Med 2014;24:313-8.

84. Sharma KK, Saikia R, Kotoky, Kalita JC, Devi R. Antifungal activity of Solanum melongena L, Lawsonia inermis L, Justicia gendarussa B against dermatophytes. Int J PharmTech Res 2011;3:1635-40.

85. Rahmoun N, Boucherit Otmani Z, Boucherit K, Benabdallah M, Choukchou-Braham N. Antifungal activity of the Algerian Lawsonia inermis (henna). Pharm Biol 2013;51:131-5.

86. Singla S, Gupta R, Puri A, Singh V, Roy S. Comparison of anticandidal activity of Punica granatum (pomegranate) and Lawsonia inermis (henna leaves): an in vitro study. Int J Dental Res 2013;1:8-13.

87. Ismail KA, Ibrahim AN, Ahmed MA, Hetta MH. Comparison between the effect of Lawsonia inermis and flubendazole on Strongyloides species using scanning electron microscopy. J Parasit Dis 2016;40:415-22.

88. Singh DK, Cheema HS, Saxena A, Jyotshana Singh S, Darokar MP, Bawankule DU, et al. Fraxetin and ethyl acetate extract from Lawsonia inermis $\mathrm{L}$ ameliorate oxidative stress in $P$. berghei infected mice by augmenting antioxidant defence system. Phytomedicine 2017;36:262-72.

89. Al-Ogaili N. Synergistic effect of Lawsonia inermis and Peganum harmala aqueous extracts on in vitro growth of Leishmania tropica promastigotes comparison to sodium stibogluconate. Al-Qadisiyah Med J 2016;12:76-83.

90. Motazedian MH, Mikaeili F, Mohebali M, Miri R, Habibi $\mathrm{P}$, Kamarloie S. The antileishmanial effects of Lawsonia inermis and Cedrus libani on Leishmania major promastigotes: an in vitro study. J Parasit Dis 2017;41:375-9.

91. Serakta M, Djerrou Z, Mansour Djaalab H, Kahlouche Riachi F, Hamimed S, Trifa W, et al. Antileishmanial activity of some plants growing in Algeria: Juglans regia, Lawsonia inermis and Salvia officinalis. Afr J Tradit Complement Altern Med 2013;10:427-30.

92. Anna T, Harikrishnan TJ, Meenakshisundaram A, Arunachalam K, Suriya K, Narendran RR. Anticoccidial effects of Lawsonia inermis against caecal coccidiosis in broilers. 2016;2:246.

93. Wurochekke $\mathrm{AU}$, Chechet $\mathrm{G}$, Nok AJ. In vitro and in vivo anti trypanosomal activity of the leaf of Lawsonia inermis against Trypanosoma brucei infection in mice. J Medical Sci 2004; 4:236-9.

94. Tauheed AM, Shittu SH, Suleiman MM, Habibu B, Kawu $\mathrm{MU}$, Kobo PI, et al. In vivo ameliorative effects of methanol leaf extract of Lawsonia inermis linn on experimental Trypanosoma congolense infection in wistar rats. Int J Vet Sci Med 2016;4:3340.

95. Marimuthu S, Rahuman AA, Santhoshkumar T, Jayaseelan C, Kirthi AV, Bagavan A, et al. Lousicidal activity of synthesized silver nanoparticles using Lawsonia inermis leaf aqueous extract against pediculus humanus capitis and bovicola ovis. Parasitol Res 2012;111:2023-33.

96. Bakhshi H, Abai MR, Amin G, Zolfi R, Pirmohammadi M, Bakhshi A, et al. Larvicidal properties of botanical extracts of Lawsonia inermis against Anopheles stephensi. Adv Infect Dis 2014;4:178-85.

97. Khanavi M, Vatandoost H, Khosravi Dehaghi N, Sanei Dehkordi A, Sedaghat MM, Hadjiakhoondi A, et al. Larvicidal activities of some Iranian native plants against the main malaria vector, Anopheles stephensi. Acta Med Iran 2013;51:141-7.

98. Singh A, Singh DK. Molluscicidal activity of Lawsonia inermis and its binary and tertiary combinations with other plant derived molluscicides. Indian J Exp Biol 2001;39:263-8.
99. Kumar M, Chandel M, Kaur P, Pandit K, Kaur V, Kaur S, et al Chemical composition and inhibitory effects of water extract of henna leaves on reactive oxygen species, DNA scission and proliferation of cancer cells. EXCLI J 2016;15:842-57.

100. Hossain MA. In vitro determination of antioxidant capacity for methanolic extract of Eichhornia crassipes, Lawsonia inermis L and Cissus quadrangularis L By DPPH (1,1-diphenyl-2picrylhydrazyl) free radical scavenging assay. Bachelor thesis, East West University, Dhaka; 2008.

101. Hasan KM, Yesmin S, Akhter SF, Paul S, Sarker S, Islam A, et al. Hepatoprotective potentiality of various fractions of ethanolic extracts of Lawsonia inermis (henna) leaves against chemicalinduced hepatitis in rats. Biochem Mol Biol 2016;1:17-22.

102. Philip Jacob P, Madhumitha G, Mary Saral A. Free radical scavenging and reducing power of Lawsonia inermis L seeds. Asian Pac J Trop Med 2011;4:457-61.

103. Kumar M, Kaur P, Chandel M, Singh AP, Jain A, Kaur S Antioxidant and hepatoprotective potential of Lawsonia inermis $\mathrm{L}$ leaves against 2-acetyl amino fluorene induced hepatic damage in male wistar rats. BMC Complement Altern Med 2017;17:56.

104. Mohamed MA, Eldin IM, Mohammed AE, Hassan HM. Effects of Lawsonia inermis L. (henna) leaves' methanolic extract on carbon tetrachloride-induced hepatotoxicity in rats. J Intercult Ethnopharmacol 2015;5:22-6.

105. Darvin SS, Esakkimuthu S, Toppo E, Balakrishna K, Paulraj MG, Pandikumar P, et al. Hepatoprotective effect of lawsone on rifampicin-isoniazid induced hepatotoxicity in in vitro and in vivo models. Environ Toxicol Pharmacol 2018;61:87-94.

106. Latha PG, Suja SR, Shyamala S, Rajasekharan S. Some hepatoprotective garden plants. Nat Prod Radiance 2005;4:278-9.

107. Anand KK, Singh B, Chand D, Chandan BK. An evaluation of Lawsonia alba extract as hepatoprotective agent. Planta Med 1992;58:22-5

108. Hsouna AB, Mongi S, Culioli G, Blache Y, Ghlissi Z, Chaabane $\mathrm{R}$, et al. Protective effects of ethyl acetate fraction of Lawsonia inermis fruits extract against carbon tetrachloride-induced oxidative damage in rat liver. Toxicol Ind Health 2016;32:694706.

109. Ahmed S, Saeed A, Asadullah M. Effectiveness of Lawsonia inermis for psychopharmacological activity on staircase in NMRI mice. Med Forum 2016;27:2-4.

110. Ahmed S, Iqbal J. Aniolytic effect of Lawsonia inermis (henna) on light dark boxactivity. World J Pharm Pharm Sc 2014;3:1334-9.

111. Pal SC, Kasture VS, Kasture SB. Effect of Lawsonia inermis on memory and behavior mediated via monoamine neurotransmitters. Indian J Pharmacol 1998;30:181-5.

112. Ali BH, Bashir AK, Tanira MO. Anti-inflammatory, antipyretic, and analgesic effects of Lawsonia inermis L (henna) in rats. Pharmacology 1995;51:356-63.

113. Imam H, Mahbub NU, Khan MF, Hana HK, Sarker MM. Alpha amylase enzyme inhibitory and anti-inflammatory effect of Lawsonia inermis. Pak J Biol Sci 2013;16:1796-800.

114. Ramya A, Vijayakumar N, Renuka M. Antiarthritic effect of Lawsonia inermis $\mathrm{L}$ an in vitro study. Int J Modn Res Revs 205;3:744-7.

115. Ziaei A, Sahranavard S, Gharagozlou MJ, Faizi M. Preliminary investigation of the effects of topical mixture of Lawsonia inermis $\mathrm{L}$ and Ricinus communis $\mathrm{L}$ leaves extract in treatment of osteoarthritis using MIA model in rats. Daru 2016;24:12.

116. Manivannan R, Aeganathan R. Analgesic activity of Lawsonia inermis leaves extract in swiss albino mice. Pharm Biol Evaluations 2016;3:360-5.

117. Kumari P, Singh N, Kumar D. Synergistic analgesic activity of chloroform extract of Lawsonia inermis linn and Chlorophytum borivilianum sant. J Pharm Phytochem 2015;3:35-8.

118. Sultana S, Khosru KH. Analgesic and antidiarrhoeal activity of Lawsonia inermis. Int J Pharma Sci Res 2011;2:3183-8.

119. Nayak BS, Isitor G, Davis EM, Pillai GK. The evidence based wound healing activity of Lawsonia inermis linn. Phytother Res 2007;21:827-31. 
120. Galehdari H, Negahdari S, Kesmati M, Rezaie A, Shariati G Effect of the herbal mixture composed of Aloe vera, henna, Adiantum capillus-veneris, and myrrha on wound healing in streptozotocin-induced diabetic rats. BMC Complement Altern Med 2016;16:386.

121. Mutluoglu M, Uzun G. Can henna prevent ulceration in diabetic feet at high risk? Hindawi Publishing Corporation Experimental Diabetes Research; 2009. http://dx.doi.org/10.1155/2009/ 107496.

122. Hadisi Z, Nourmohammadi J, Nassiri SM. The antibacterial and anti-inflammatory investigation of Lawsonia inermis-gelatinstarch nano-fibrous dressing in burn wound. Int J Biol Macromol 2018;107(Pt B):2008-19.

123. Sakarkar DM, Sakarkar UM, Shrikhande VN, Purohit RN. Wound healing properties of henna leaves. Nat Prod Radiance 2004;3:406-12.

124. Hekmatpou D, Ahmadian F, Eghbali M, Farsaei S. Henna (Lawsonia inermis) as an inexpensive method to prevent decubitus ulcers in critical care units: a randomized clinical trial. J Evid Based Integr Med 2018;23:2515690 X18772807. DOI: $10.1177 / 2515690 X 18772807$.

125. Esteki R, Miraj S. The abortificient effects of hydroalcoholic extract of Lawsonia inermis on BALB/c mice. Electronic Physician 2016;8:2568-75.

126. Aguwa CN. Toxic Effects of the methanolic extract of Lawsonia inermis roots. Pharm Biol 1987;25:241-5.

127. Mikhaeil BR, Badria FA, Maatooq GT, Amer MMA. Antioxidant and immunomodulatory constituents of henna leaves. Zeitschrift Fuer Naturforschung Section C J Biosci 2004;59:468-76.

128. Dikshit V, Dikshit J, Saraf M, Thakur V, Sainis K. Immunomodulatory activity of naphthoquinone fraction of Lawsonia inermis linn. Phytomedicine (Jena) 2000;7:102-3.

129. Zubardiah L, Sudiono J. Effectiveness of Lawsonia inermis L leaves methanol extracts on gingivitis healing (In vivo study on sprague dawley rats). Br J Med Med Res 2016;15:1-8.

130. Zubardiah L, Mustaqimah DN, Auerkari EI. Effectiveness of Lawsonia inermis linneaus leaves infusion in gingivitis healing. Dentika Dental J 2012;17:105.

131. Patel KM, Shah SK. Evaluation of antiurolithiatic activity of Lawsonia inermis in rats. Int J Pharma Sci Nanotec 2017;10:3728-35.

132. Kore KJ, Shete RV, Jadhav PJ, Kabra MP. Antiurolithiatic effects of hydroalcoholic extract of Lawsonia inermis L leaves. Int J Universal Pharm Life Sci 2011;1:81-95.

133. Singh S, Verma N, Karwasra R, Kalra P, Kumar R, Gupta YK. Safety and efficacy of hydroalcoholic extract from Lawsonia inermis leaves on lipid profile in alloxan-induced diabetic rats. Ayu 2015;36:107-12.

134. Antika MA, Ilyas SA, Sari MI. Effect of Lawsonia inermis linn ethanol extract on the superoxide dismutase activity in hyperglycemic Rattus norvegicus. Indonesian J Med 2017;2:7985.

135. Arayne MS, Sultana N, Mirza AZ, Zuberi MH, Siddiqui FA. In vitro hypoglycemic activity of methanolic extract of some indigenous plants. Pak J Pharm Sci 2007;20:268-73.

136. Abdillah S, Budiady I, Winarno H. Hypoglycaemic and antihyperlipidemic effects of henna leaves extract (Lawsonia inermis linn) on alloxan induced diabetic mice. Jordan J Pharm Sci 2008;1:126-31.

137. Goswami M, Kulshreshtha M, Rao CV, Yadav S, Yadav S. Antiulcer potential of Lawsonia inermis L leaves against gastric ulcers in rats. J Appl Pharm Sci 2011;1:69-72.

138. Candra KRY, Sandya LSD, Ruth SK, Nagarjuna S, Padmanabha RY. Evaluation of diuretic activity of aqueous and ethanolic extracts of Lawsonia inermis leaves in rats. Asian J Plant Sci Res 2011;1:28-33.

139. Pradhan R, Dandawate $P$, Vyas A, Padhye S, Biersack B, Schobert $\mathrm{R}$, et al. From body art to anticancer activities: perspectives on medicinal properties of henna. Curr Drug Targets 2012;13:1777-98.

140. da Silva AJ, Buarque CD, Brito FV, Aurelian L, Macedo LF, Malkas LH, et al. Synthesis and preliminary pharmacological evaluation of new (+/-) 1,4-naphthoquinones structurally related to lapachol. Bioorg Med Chem 2002;10:2731-8.

141. Kemp AJ, Lyons SD, Christopherson RI. Effects of acivicin and dichloroallyl lawsone upon pyrimidine biosynthesis in mouse L1210 leukemia cells. J Biol Chem 1986;261:14891-5.

142. Kamei H, Koide T, Kojima T, Hashimoto Y, Hasegawa M. Inhibition of cell growth in culture by quinones. Cancer Biother Radio Pharm 1998;13:185-8.

143. Abdel Hamid NM, Mohafez OM, Nazmy MH, Farhan A, Thabet K The effect of co-administration of Lawsonia inermis extract and octreotide on experimental hepatocellular carcinoma. Environ Health Prev Med 2015;20:195-203.

144. Li Q, Gao W, Cao J, Bi X, Chen G, Zhang X, et al. New cytotoxic compounds from flowers of Lawsonia inermis L. Fitoterapia 2014; $94: 148-54$.

145. Ozaslan M, Zumrutdal ME, Daglioglu K, Kilic IH, Karagoz ID. Antitumoral effect of Lawsonia inermis in mice with EAC. Int Pharmacol 2009;5:263-7.

146. Zumrutdal ME, Ozaslan M, Tuzcu M, Kalender ME, Dagloglu K Effect of Lawsonia inermis treatment on mice with sarcoma. Afr J Biotechnol 2008;7:2781-6.

147. Priya R, Ilavenil S, Kaleeswaran B, Srigopalram S, Ravikumar S. Effect of Lawsonia inermis on tumor expression induced by dalton's lymphoma ascites in swiss albino mice. Saudi J Biol Sci 2011;18:353-9.

148. Endrini S, Rahmat A, Ismail P, Taufiq-Yap YH. Comparing of the cytotoxicity properties and mechanism of Lawsonia inermis and Strobilanthes crispus extract against several cancer cell lines. J Med Sci 2007;7:1098-102.

149. Endrini S, Rahmat A, Ismail P, Taufiq Yap YH, Othman F. Effects of henna (Lawsonia inermis) on the apoptotic pathway of human liver carcinoma cell lines. J Appl Sci Res 2011;7:321-6.

150. Dasgupta T, Rao AR, Yadava PK. Modulatory effect of henna leaf (Lawsonia inermis) on drug metabolising phase I and phase II enzymes, antioxidant enzymes, lipid peroxidation and chemically induced skin and forestomach papillomagenesis in mice. Mol Cell Biochem 2003;245:11-22.

151. Kapadia GJ, Rao GS, Sridhar R, Ichiishi E, Takasaki M, Suzuki N, et al. Chemoprevention of skin cancer: effect of Lawsonia inermis L (henna) leaf powder and its pigment artifact, lawsone in the epstein-barr virus early antigen activation assay and in two-stage mouse skin carcinogenesis models. Anticancer Agents Med Chem 2013;13:1500-7.

152. Nakashima S, Oda Y, Nakamura S, Liu J, Onishi K, Kawabata $\mathrm{M}$, et al. Inhibitors of melanogenesis in B16 melanoma 4A5 cells from flower buds of Lawsonia inermis (henna). Bioorg Med Chem Lett 2015;25:2702-6.

153. Ong CY, Ling SK, Ali RM, Chee CF, Samah ZA, Ho AS, et al. Systematic analysis of in vitro photocytotoxic activity in extracts from terrestrial plants in Peninsula Malaysia for photodynamic therapy. I Photochem Photobiol B Biol 2009;96:216-22.

154. Yogisha S, Samiulla DS, Prashanth D, Padmaja R, Amit A Trypsin inhibitory activity of Lawsonia inermis. Fitoterapia 2002;73:690-1.

155. Abdelgadir EH, Ahmed RH, Adam SI, Husein AM. Evaluation of toxicological activity (acute and sub-chronic toxicities) of the aqueous extract of Lawsonia inermis seeds on wistar rats. J Pharmacol Toxicol 2010;5:324-33.

156. Scientific Committee on Consumer Safety, SCCS. Lawsonia inermis (henna). SCCS/1511/13, 19 09; 2013.

157. Singh VK, Pandey DK. Fungitoxic studies on bark extract of Lawsonia inermis against ringworm fungi. Hindustan Antibiot Bull 1989;31:32-5.

158. Agabna NME, Shaddad SAI, Mudathir AK. Safety of Lawsonia inermis ethanolic seeds extract. J Pharm Biomed Sci 2014;04:303-9.

159. Khine YY. Acute kidney injury following Ingestion of henna leaf extract: a case report from Myanmar. Blood Purif 2017;44 Suppl 1:41-5. 